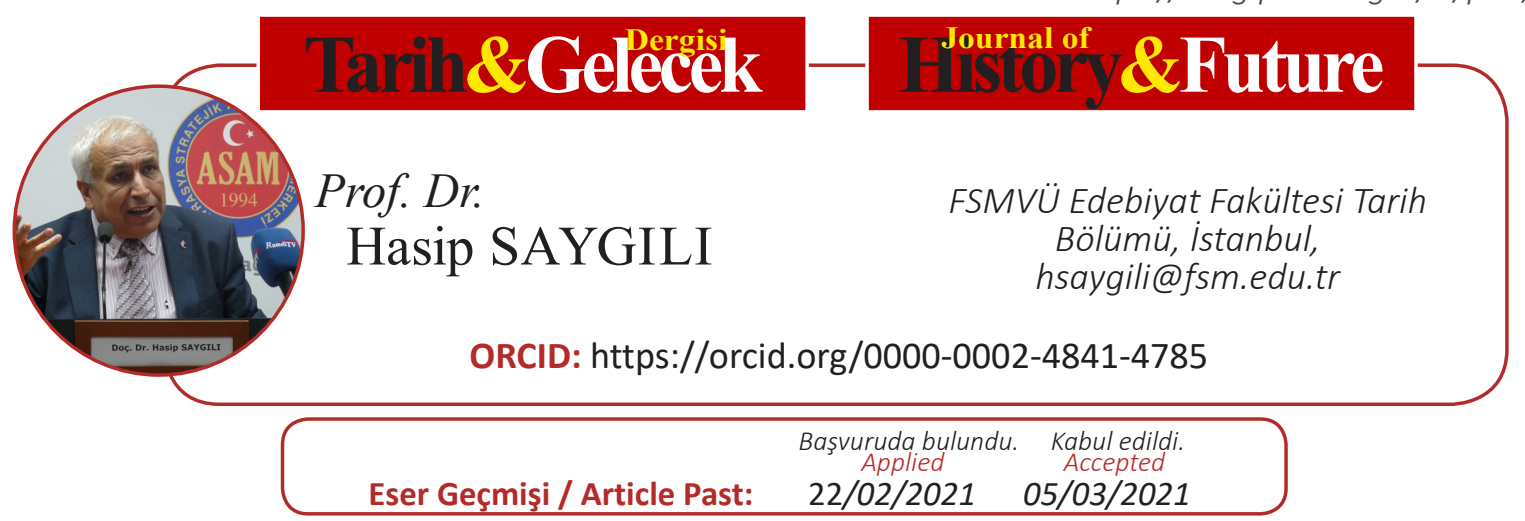

Araştırma Makalesi DOI: http://dx.doi.org/10.21551/jhf.884588

Orjinal Makale / Orginal Paper

\title{
Osmanl1-Rus Kafkas Cephesinde Kars Savunması (1828-1878)
}

\author{
The Defense of Kars at Ottoman-Russian Caucasus Front (1828-1878)
}

\section{$\ddot{\mathbf{O z}}$}

19. yüzyılda 50 yıl içinde yapılan üç savaşta da Kars kale garnizonu Rusların eline geçmiştir. Bu kronik zaafın askeri, siyasi ve insan malzemesine yönelik sebepleri yeterince incelenmiş değildir. Türk tarih yazımında daha ziyade münferit başarıların öne çıkarıldığı hamasi bir dil tercih edilmiştir. Harp tarihi incelemesi yapmakla görevli resmi kurumların yayınlarında da münferit eleştiriler dışında felaketin temel sebepleri üzerinde derinlikli değerlendirmelerden kaçınılmıştır. Bu makalede Kars'ın bir nesil içinde üç defa düşüşünün farklı kaynaklara dayalı analizi yapılmıştır. Silahlı Kuvvetlerin dönem boyunca baş edemediği köklü bünyevi problemler yanında belki bunlardan daha önemlisi insan kalitesi zaaflarının askeri mağlubiyete zemin teşkil ettiği yönünde bulgulara ulaş1lmıştır.

Anahtar kelimeler: Kars kalesi, Kafkas cephesi, Gazi Ahmet Muhtar Paşa, Osmanlı-Rus Savaş1

\section{Abstract}

In the 19th century, Kars fortress had been invaded by the Russians three times during three wars waged in fifty years. The military, political and human capital-related causes of this chronic frailty have not been investigated thoroughly yet. In Turkish histography, the heroic language has been rather used in which disjunctive accomplishments are put forward. In publishings of official institutions that are responsible for war history studies, deep investigations on basic causes of the calamity have been avoided except for the isolated critics. In this study, the fall of Kars fortress has been analyzed based on various sources. In the light of the data analysis, it has been found that frailty of human quality has been regarded as a basis for military defeat constitution along with the intrinsic problems that the army could not cope with during the mentioned era.

Keywords: Castle of Kars, Caucasus Front, Gazi Ahmet Muhtar Pasha, Ottoman-Russia War 


\section{Giriş}

9. yüzyıl boyunca Türk-Rus savaşlarının Anadolu coğrafyasında düğüm noktası
Kars olmuştur. Doğu Anadolu'yu Güney Kafkasya'ya bağlayan en kısa yol
üzerinde bulunan şehrin stratejik önemi açıktır. ${ }^{1}$ Kars Doğu Anadolu'da Rus
muharebelerinde cephe hattının merkezini teşkil etmiştir. ${ }^{2}$ Soğanlı Dağlarında
doğan Kars Çayı'nın güneybatıdan kuzeydoğu istikametinde yarattığ havza üzerinde bulunan Kars şehri denizden 1800 metre yüksekliktedir.

Kars'ın asıl kale kısmı o zaman doğudaki kısmın güneyinde bulunmaktaydı. Kars Çayının güney sahilindeki tepeler şehre hâkim bir durumda olmalarına rağmen şehrin kuzeyinde kayalık tepelerde bulunan iç kaleden daha alçak bir konumdaydılar.

Kars Kalesi iç ve diş kale ile bunların arasındaki orta hisardan meydana geliyordu. Dış kale: iki sıra kâgir duvardan surlarla ve bunları çevreleyen siperlerden meydana gelmekteydi. İç kale, üç sıra surla çevrilmişti. Farklı dönemlerde inşa edilmiş tabya ve istihkâmların bir kısmı da kuzeydoğusundaki Karadağ Tepeleri üzerinde bulunuyordu. Kalenin varoşlarında özellikle batı, kuzeybatı ve kuzeydoğusundaki varoşlardaki tabyaların birbirleriyle irtibatı yoktu. Kaledeki dönem boyunca çeşitli çapta eski model toplar da bulunuyordu. ${ }^{3}$

Kars Çayı'nın ikiye ayırdığı bölgenin doğusu açık ve düzlük batısı dağlık ve engebeli yüksek rakımlı arazilerden meydana gelmektedir. Arazinin bu tabiatı Rus ordusunun Kars garnizonu önüne kadar gelebilmesinin her zaman kolaylaştırmıştır.

Çarlığın Erzurum'u hedefleyen ana yaklaşma istikameti Tiflis-Gümrü üzerinden Kars'a el atarken yine Tiflis-Ahıska-Ardahan istikameti de Oltu üzerinden veya Kars üzerinden Erzurum'u hedeflemiştir. Erzurum'u hedefleyen bir diğer istikamet Tiflis-Gümrü-Erivan-Doğu BayezitKaraköse(Ağrı)-Hasankale olmuştur. İncelediğimiz dönem boyunca bu istikametlerin ulaşım yeteneği doğal olarak araziye tabi olmuştur. Ancak incelediğimiz dönem boyunca Kars, Sarıkamış üzerinden vilayet merkezi Erzurum'a dönemine göre iyi sayılabilen bir yolla bağlıydı. Ayrıca yine Kars'tan kuzeyde Ardahan'a, doğuda Gümrü'ye giden yollar mevcuttu. ${ }^{4}$

19. yüzyıl boyunca Kars şehrine Rus ordusu 1807, 1828-1829, 1854-1855 ve 1877-1878 yıllarında olmak üzere dört defa gelmiştir. 1807 yılında Arpaçay’1 geçerek Kars’a gelen Ruslar, Yenimahalle, Temürpaşa ve Bayrampaşa mahallelerinde yapılan boğaz boğaza meskûn mahal muharebelerinde yenilerek geri çekilmişledir. Bu muharebelerde sivil mahalli halkın da ordu ile

1 Bnb. İzzet, İstiklal Mücadelesinde Kars Müstahkem Mevkiine Yapılan Taarruz ve Bu Taarruzdan Alınan Dersler, Askerî Mecmua, 49. Cilt, Nisan 1931, sayı 80, s. 213. Karl Marks'a göre ise Kars Erzurum'un anahtarı; Erzurum da İstanbul'un ve Anadolu stratejik ve ticari hatlarının anahtarıdır. Karl Marx, The Eastern Question A Reprint of Letters written 1853-1856 dealing with the events of the Crimean War, (London: Swan Sonnenschein and Co. Limp, 1897), s. 613.

2 Mehmed Arif Bey, Başımıza Gelenler, c. 1, (haz.) M. Ertuğrul Düzdağ, (İstanbul: Tercüman 1001 Temel Eser, ty), s. 60.

3 Naci Çakın, Türk Silahlı Kuvvetleri Tarihi, c. 3, 5nci Kısım Eki Osmanlı-Rus Harbi (1828-1829) Etüt, (Ankara: Genelkurmay Basımevi, 1978), s. 153.

4 Çakın, age, s.153. 
beraber şehrini savunduğu bilinmektedir. ${ }^{5}$

1828-1878 arasındaki yarım asırlık zaman diliminde Kars şehri üç defa kuşatılmış ve her üçünde de Rusların eline geçmiştir. Bu çalışmada Kars'ın etkin şekilde savunulamayışının sebepleri ortaya konmaya çalışılmıştır.

\section{8-1829 Savaşı}

1828 Rus Harbi kaçınılmaz hale gelirken Kars Kalesi'nin tahkimatı ve savunma kabiliyeti artırılamamış haldeydi. Savaş doğu cephesinde 1828 Mayıs ayı ortalarında Rus taarruzu ile Batum kuzeyinde deniz ve karadan başlamıştı. Anapa'daki Türk kuvvetlerinin bertaraf edilmesi ve geri bölgedeki Çerkez tehditlerinin ortadan kaldırılmasından sonra Gümrü'de toplanan 10 bin kişi ve 70 top kuvvetinde General İvan Paskeviç komutasındaki Rus ordusu ${ }^{6} 28$ Haziran 1828 günü hudut olan Arpaçay’1 geçerek Kars üzerine yürümüştü. 1 Temmuz'da Kars Kalesi'ne keşfe başlayan Ruslar, Erzurum'dan Kars'a gelebilecek takviyeyi karşılayabilmek için şehrin güneyinde tertiplenmişti. Keşif sonuçlarına göre de şehrin batısında takviyeli bir tugay konuşlandırmış ve 5 ve 6 Temmuz günleri topçu ateşleriyle kaleyi ve tabyaları taarruz için olgun hale getirmeye çalışılmıştır. 7 Temmuz günü erken saatlerden itibaren tekrarlanan topçu ateşlerinden sonra Rus kuvvetleri şehrin batısındaki mezarlık civarındaki tabyalara taarruza başlamıştı. Buradaki birlikleri geri atan Rus birlikleri geriye çadırlı ordugâha kadar sokulmaya başlamışlarsa da Osmanlı karşı taarruzu ile geri püskürtülmüşlerdi. Tekrarlanan Rus taarruzu Türklerin boğaz boğaza direnmelerine ve Ruslara ağır zayiat verdirmelerine rağmen, kendilerinin de büyük kayıpları yüzünden geriye çekilmelerine sebep olmuştur. Rus birlikleri bu suretle mezarlık bölgesinde şehre hâkim tepeleri ele geçirmişlerdi. Bölgedeki tabyalar her iki tarafın ağır zayiatına tanık oldukları için anılan tarihten itibaren Kanlı Tabya olarak adlandırılacaktı. ${ }^{7}$

Şehre hâkim tepelerin ele geçirilmesi üzerine şehrin doğusundaki süvari birlikleri de doğudaki tabyalara taarruza geçirilmişti. Bu kuvvetler kısa zamanda tabyaları ele geçirerek şehrin varoşlarını tutarken batıdaki birlikler de kale kapısını ele geçirmişlerdi. Kale Komutanı Emin Paşa bir kısım kuvvetle iç kaleye çekilmişti. Erzurum' dan beklenen yardım kuvvetinden ümit kesilmesi ve mahalli halkın ısrarı üzerine ${ }^{8} 7$ Temmuz 1828 günü "Osmanlı Kafkas savunmasının gururu" Kars ilk defa Rusların eline geçmiş oluyordu. Bu durum Osmanlı Kafkas savunmasını tamamen yok etmiş ve bölgede şok yaratmıştı. ${ }^{10}$

Kars Kalesi'nde bulunan 11 bin kişilik kuvvetten kurtulabilen bir kısım süvari hariç kalanı ölmüş, dağılmış veya Ruslara esir düşmüştü. Kars'ın sivil halkının da işgal ordusu tarafından

5 M Fahrettin Kırzıoğlu, Kars Tarihi, c. 1., (İstanbul: Iş11 Matbaası, 1953), s. 547-548.

6 Konuya ilişkin bir kaynağa göre muharip Rus kuvvetlerinin sayısı zaten hemen hiçbir zaman 15 binden fazla olmamıştır. John F. Baddeley, The Russian Conquest of the Caucasus, (London: longmans, 1908), s. 184.

$7 \quad$ Kırzığlu, Kars Tarih, age, s. 549.

8 Osmanlı Arşiv kaynaklarına göre de Kars Müftüsünün savunma esnasında Ruslarla işbirliği yaptığ1 ortaya çıkmış, adı geçen daha sonra cezalandırılmıştır. Yaşar Kop, 1828-1829 Osmanlı-Rus Savaşı’nda Kars ve Çevresi, (Erzurum: Atatürk Üniversitesi, 1999), s. 118.

9 Ahmed Muhtar,1244-45[1828-29], Türkiye-Rusya Seferi, Cild-i evvel, (Ankara: Büyük Erkân-1 Harbiye Reisliği, 1928), s. 217

10 Mesut Uyar ve Edward J Erickson, A Military History of the Ottomans, (Santa Barbara: ABC Clio, 2009), s. 138. 
mağdur edildiği anlaşılmaktadır. Vatan Şairi Namık Kemal'in de Kars'ta hocalığını yapmış Büyük Hamid Efendi'nin mersiyesinde Rusların kaleye hücumları anlatılırken "pay-i mal oldu nice nisvanımız sibyanımız" "I ifadesinden muharip olmayan Türk kadın ve çocuklarının katledildikleri ve şereflerine leke sürüldüğü anlaşılmaktadır. Rusların zayiatı ise 14 subay ve 4 bin er olmuştu. ${ }^{12}$ Ruslar Kars Kalesi Komutanı Emin Paşa ve 1.800 askeri esir olarak Tiflis’e götürmüş, geri kalan askerlerin silah ve teçhizatını aldıktan sonra serbest bırakmışlardı. Kars'ın yardımına gelen Seyyar Ordu Komutanı Köse Mehmed Paşa şehre 10 km. kadar yaklaşmışken şehrin düştügünü öğrenince kuzeye Ardahan'a hareket etmişti. Bölgedeki Ermeniler de Rus zaferini sevinçle karşılamışlardı. ${ }^{13}$

Kars'1 savunan birliklerin personel sayısı Rus kuvvetlerinden az olmamasına rağmen bunların çoğunluğunun eğitim görmemiş mahalli unsurlardan meydana gelmesine işaret edilmesi gerekir. Erzurum'dan Kars'a yardıma gönderilen birliklerin vaktinde şehre ulaşamamasında da disiplinden yoksun, eğitimsiz mahalli milislerden meydana geldiği hatırda tutulmalıdır.

Kars'1 ele geçiren Ruslar buradan esas hedefleri olan Erzurum'a doğru harekete geçmişlerdi. ${ }^{14}$ Kars 14 Eylül 1829 tarihinde Ruslarla imzalanan Edirne Andlaşması gereği 26 Haziran 1830 günü tahliye edilmiştir. Rusların tahliye ettiği şehirdeki evlerin tahrip edildiği ve işe yarar malzemenin Rusya’ya götürüldüğü görülmüştür. İki yıllık işgal dönemi sonucunda 50 bin olan şehir nüfusu 12 bine inmiştir. ${ }^{15}$ Rus işgalinden 15 yil sonra şehri gören Alman gezgin bilgin Karl Koch şehrin hâlâ büyük kısmının harabe halde olduğunu yazmıştır. ${ }^{16}$

1735'te Nadir Şah'ın 90 bin kişilik ordusunun kuşatmasına baş eğmeyen Kars Kalesi'nin 11 bin asker ve 151 top, yeterli erzak ve su kaynakları olmasına rağmen kısa bir süre içinde teslim olmasını Baddeley "harp tarihinin en şaşırtıcı hadiselerinden birisi" olarak değerlendirmiştir. ${ }^{17}$

Kars'ın ilk defa Rusların eline geçtiği 1828 yılında felaketin geniş çerçevede insan kalitesindeki yetersizliklerden kaynaklandığı bazı edebiyat ürünlerine de yansımıştır. Prof. Dr. Fahrettin Kırzıoğlu'nun tespit ettiği dönemin Erzurum Müftüsü Dursun Ahmet Natıkî'nin şiirlerinde sosyal çözülme emareleri açıklıkla tasvir edilmiştir. Müftü Efendiye göre erkeklerde namus ve yiğitlik izi kalmamış, padişah tecrübesiz, yetkililer gaflette, "paşa, vezir, beğ"de insaf kalmamış, devlette üst derece makam sahipleri özlük hakları için birbirleriyle savaşmakta idiler. Hatta üst seviye kamu görevlilerinin hepsi düşman karşısında "hain çıkmıştı" ve bu yüzden düşman başarı kazanmışt. ${ }^{18}$

11 M Fahrettin Kırzıŏlu, 100. Yıldönümü Dolayısıyla 1855 Kars Zaferi, (İstanbul: Iş11 Matbaası, 1955), s. 27.

12 Çakın, age,s.153-156. Ayrıca bkz. Ahmed Muhtar, s. 217. Harekâta Rus ordusuyla katılan bir İngiliz subayının yazdığı monografiye göre ise Rusların zayiatı 13 subay ve 400 erden ibarettir. W. Monteith, Kars and Erzeroum with campaigns of Prince Paskiewitch in 1828 and 1829,(London: Longman, 1856), s. 166.

13 W E D Allen ve Paul Muratoff, 1821-1921 Türk - Kafkas Sinırındaki Harplerin Tarihi, (Ankara: Genelkurmay Basımevi, 1966), s. 39. Savaştan sonra da önemli bir Ermeni nüfus Rus ordusuyla beraber Osmanlı hudutlarının dışına çekilmişti.

14 Naci Çakın, Nafiz Orhon, Türk Silahlı Kuvvetleri Tarihi III. Cilt, 5nci Kısım (1793-1908), (Ankara: Genelkurmay Basımevi, 1978), s. 441.

15 Kop, age, s. 121-122.

16 Karl Emil Heinrich Koch, Reise im Pontischen Gebirge und Turkischen Armenien, (Weimar: 1846), s. 159.

17 Baddeley, s. 185.

18 Kırzıoğlu, 1855 Kars Zaferi, age, s. 27-28. 


\section{"1855 Kars Zaferi”}

Kırım Harbi’ne (1853-1856) doğru Rusya ile diplomatik ilişkiler kopunca Osmanlı Devleti askeri hazırlıklara hız vermeye başlamıştı. Rusya ile bir savunma savaşı öngören Osmanlı Seraskerliği (Genelkurmay Başkanlığı) Rumeli Ordusuna olduğu gibi Anadolu Ordusuna da gönderdiği bir emirle mevcut kuvvetlerin "ihtiyat kaidesine riayeten uyanık bulunması" ile asker, mühimmat vb. ihtiyaçların temin edilmesini istemişti. Ancak bölgede bu ihtiyaçları karşılayacak

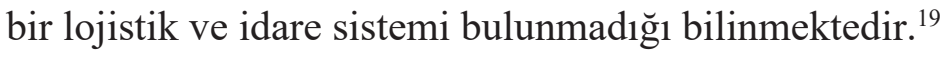

Osmanlı Devleti, Eflak ve Buğdan'ın Rus kuvvetleri tarafından işgali üzerine ana yaklaşma istikameti üzerindeki Kars Kalesi’nin tahkimatının güçlendirilmesine öncelik vermişti. 1853 yazı boyunca bölgeye önemli sayılabilecek yığınak yapıldı. ${ }^{20}$ Söz konusu dönemde Rus istihbaratı Kars ve çevresindeki mahalli sivil halkın mukavemetini kırmak için gönderdikleri ajan ve muhacirlerle tehdit ve propagandayı da ihmal etmemişti: "Geçen defa muharebe ile aldığımı Kars Kalesi'ni Edirne Muahedesiyle geri verdik amma, bu defa alınca artık elimizden çıkarmayacağı; Karslılar akıllarını başlarına toplasınlar da 1828 deki gibi karşı koyarak boşuna kırılmasınlar...” Rus propagandasına karşı ise Âşık Bahri ve Şüregelli Kulu gibi halk âşıklarının söyledikleri Rus karşıtı koçaklamalar ile halkın maneviyatı korunmaya çabalanmıştır. Bu koçaklamalardan bazıları ordu mızıkası tarafından bestelenerek çalırmıştır. ${ }^{21}$

1853 Kasım’ında Osmanlı ve Rus birlikleri Kafkas hududunda birkaç defa karşılaşmışlardı. Bu karşılaşmalardan en dikkate değeri Kars'ın 36 km. doğusunda Gümrü yolu üzerinde Arpaçay’ın güneyinde Başgedikler'deki muharebe idi ve Rusların üstünlüğü ile sonuçlanmıştı. Plansız ve hazırlıksız olarak muharebeye girilmesi ve Osmanlı birlik komutanlarının gerekli formasyondan yoksunluğu yanında birliklerin aşırı şekilde küçük unsurlara ayrılmasının başarısızlıkta rolüne işaret edilmektedir. ${ }^{22}$ Bu başarısızlık Rusların 1854 baharına kadar bölgede güvenlik içinde kalmalarına imkân verecektir. ${ }^{23} 1854$ yılı Mart'1na kadar bölgede yetersizlikleri görülen generaller görevden alınmış Anadolu Ordusu Komutanlığına Zarif Mustafa Paşa tayin edilmiştir. Bu ara haziran ayında Bayazıd'ın Rusların eline geçmesi Kars'ın durumunu daha riskli hale getirecekti. ${ }^{24}$

1854 y1lı yazında Osmanlı Devleti, Güney Kafkasya'ya ileri bir harekât yerine tahkimli ordugâh durumundaki Kars'ın savunmasını güçlendirmeyi tercih etmiş görünmektedir. Şehre

19 Ordu Müşiri olarak bölgede görev yapan Zarif Mustafa Paşa hatıralarında Rusların Kars’a yaklaşmaları üzerine başıbozukları nasıl güçlükle harekete geçirmeye çalıştı̆̆ını anlatmaktadır. Diğer taraftan savaş başlarken ordunun depolarında bir çift çorap veya kazma küreğin dahi olmadığını ifade eden müşir paşa etraf köy ve kasabalardan ordu ihtiyacı için aba, çorap, yemeni gibi giyecekler tedarik edilmeye çalışıldığını yazmaktadır. Enver Ziya Karal, “Zarif Paşa’nın Hatıraları 1816-1862”, Belleten, c. 4, No. 16, 1. Teşrin 1940, s. 476-483.

20 Hasan Şahin, 1855 Erzurum Harekâtı, (Erzurum: Atatürk Üniversitesi, 1995), s. 198-199.

21 Kırzığlu, 1855 Kars Zaferi, age, s. 55-56.

22 Şahin, age, s. 199. Bahsi geçen dönemde Osmanlı Devleti hizmetinde müşavir olarak çalışan İngiliz Amirali Adolphus Slade, bu ve bundan sonraki yenilgiler ile ilgili "generallerin harp sanatın bilmemeleri, komuta birliğinin parçalanmış olması, kötü sevk ve idare ve Osmanlı Ordusundaki yabancı danışman subayların birbirini çekememelerinden kaynaklanan kargaşa"ya işaret etmiştir. Adolphus Slade, Turkey and The Crimean War A Narrative of Historical Events, (London: Smith Elder and Co., 1867), s. 407.

23 Mustafa Budak, 1853-1856 Kırım Savaşı’nda Kafkas Cephesi, (İstanbul: İstanbul Üniversitesi, 1993), s. 189.

24 Slade, age, s. 407, 417-418. 
İstanbul'dan 2-3 alay nizamiye askeri gönderilmiştir. Ayrıca Kars'a yakın vilayetlerden gönüllü asker takviyesi yapılmıştır. Bu dönemde Ruslarla Kafkas cephesinde birkaç muharebe cereyan etmiştir. Bunların içinde en kritiği 6 Ağustos 1854 tarihindeki Kars- Gümrü yolu üzerindeki 40 km mesafedeki Kürekdere (Kurudere, Gökdere) Muharebesidir. Her iki tarafta ağır zayiat vermesine ${ }^{25}$ rağmen muharebeyi Ruslar kazanmıştır. ${ }^{26} \mathrm{Bu}$ felaket Osmanlı Ordusu için cephede taarruz kabiliyetinin tamamıyla kaybı anlamına gelecektir. ${ }^{27}$ Bölgede 1854 yılı sonlarına kadar iki taraf arasında başka bir çatışma olmamıştır.

1854 yaz aylarında Kafkas cephesinde Rusların kazandığı başarılardan rahatsız olan Osmanlı'nın bu savaşta müttefiki İngiltere "Doğudaki İngiliz çıkarlarının güvenliği için hayati öneme sahip Küçük Asya'nın savunması ile ilgili olarak"28 bölgedeki Osmanlı Ordusunun güçlendirilmesi lüzumuna inanmıştır. Bu çerçevede İngiliz Dışişleri Bakanlığı Topçu Yarbay William Fenwick Williams'ı Anadolu Ordusu Karargâhı nezdinde İngiliz Hükümeti komiseri olarak görevlendirmiştir. Williams daha önce Osmanl-İran hududunda yıllarca çalışma tecrübesi olan ve "Türklerin karakterini ayrıntılarıyla bilen" yetenekli birisi olarak bilinmekteydi. ${ }^{29} 2$ Ağustos 1854 tarihli görev talimatına göre Williams Varna'da (daha sonra Kırım'da) İngiliz Seferi Kuvvetler Komutanı Lord Raglan'ın emirlerine göre hareket edecek ve onunla doğrudan yazışma yapabilecek yetkiye sahip olacaktı. Williams'a muhatap olacağı Türk subayları ile en dostça münasebetlerini muhafaza etmesini tavsiye eden Dışişleri Bakanı "siyasi ilgi konuları" ve Türk Ordusunun yapacağı bütün harekâttan kendisinin doğrudan ayrıntılı bilgilendirilmesi talimatını vermiştir. ${ }^{30}$

25 İngiliz diplomatik raporlarına göre bu muharebede her iki tarafında aralarında generallerin de olduğu altıbiner zayiatı (ölü) vardı. Papers Relative to Military Affairs in Asiatic Turkey and the Defence and Capitulation of Kars, (London: Harrison and Sons, 1856), s. 3-4.

26 Kürekdere Muharebesinin kaybedilmesinin sebepleri arasında Osmanlı birliklerinin geniş ölçüde nizami askerlerden oluşmaması da diğer işaret edilen sebepler yanında ifade edilmiştir. Budak, age, s. 192. Kırım Harbi boyunca uluslarası ilişkiler konusunda yazdığı yazılar daha sonra "Şark Meselesi" adıyla derlenecek olan Karl Marks 1854 yılı başlarında yazdığı bir makalede Anadolu Ordusunun çoğunlukla başıbozuklardan meydana geldiği, bunların genel olarak cesur olmakla beraber disiplinden uzak, macerac1, haydutluk ve yağmaya eğilimli kimseler olduğunu ifade edecektir. Daha ilginci Marks, Anadolu'daki ordunun Rumeli Ordusu gibi komutanlarının hangi gün ne kadar mevcudu olduğunu bilebildiği disiplinli ve eğitimli bir ordu olmadığını erken bir zamanda yazabilmiştir. Marks'ın Kars'ı savunan ordu hakkındaki görüşleri daha sonra İngiliz danışman heyetinin somut gözlemlere dayanan raporları ile uyuşmaktadır. Karl Marx, The Eastern Question A Reprint of Letters written 1853-1856 dealing with the events of the Crimean War, (London: Swan Sonnenschein and Co. Limp, 1897), s. 222223.

27 Uyar ve Erickson, age, s. 148.

28 Atwell Lake, Narrative of The Defence of Kars - Historical and Military, (London: Richard Bentley, 1857), s. 1.

29 Lake, age, s. 2. Başka bir kaynak Williams'ın Türkiye'de 14 yıl "hizmet” ettiğini ileri sürmektedir. Ian Hernon, Blood in The Sand, (Sparkford: Sutton Publishing, 2001), s. 147.

30 Görev talimatına göre Yarbay Williams İran'daki İngiliz diplomatik misyonları ile de yazışabilecek, Bakanlık ve diğer diplomatik temsilciliklerle yaptığı yazışmaların kopyasını Kırım'daki Seferi Kuvvetler Komutanı Lord Raglan’a gönderecektir. Osmanlı Hükümetinin dikkatine sunulacak hususlar Lord Raglan tarafından tasvip edildiği takdirde komutanın kendisi İstanbul'daki İngiliz Büyükelçisinden konunun Babıali'nin dikkatine sunulmasını talep edecektir. Aynı gün verilen başka bir talimatla Yarbay Williams'a İstanbul Hükümetinin dikkatine sunulacak konuları doğrudan İstanbuldaki İngiliz Büyükelçisine bildirmesi için yetki verilmiştir. Papers Relative to, s. 1-2. 
Yarbay Williams'a “Türk Ordusunun kendisine acil ihtiyacından” dolayı süratle İstanbul'da Türk makamlarına ulaşması bildirilmiş, kendisinin "birinci vazifesinin uzun bir süredir düzensizlik içinde bulunan Anadolu'daki Türk Ordusunun vaziyetini düzeltmek için gayret göstermek” olduğu ifade edilmiştir. ${ }^{31}$ Söz konusu görev çerçevesinde Williams'a Lord Raglan tarafından Türk makamlarının raporlarına itibar etmemesi hatırlatılmış, yakın şahsi gözlemlerle ayrıntılı raporlar hazırlaması talimatı verilmiştir. Bu talimat kapsamında birliklerin kuruluş, personel sayısı, silah, teçhizat, ikmal ve iaşesinden subay ve generallerin yetenekleri ve birbirlerine entrika kurmakla meşgul olup olmadıklarına kadar hemen her konuya ayrı ayrı işaret edilmiştir. ${ }^{32}$

15 Ağustos'ta İstanbul'a gelen Williams, 24 Eylül'de Erzurum üzerinden Kars'a gelecek ve büyük bir törenle karşılanacaktır. Kars’ta kendisinin maiyetine verilmiş emir subayı Binbaşı Teesdale ile Doktor Humpry Sandwith de bulunmaktadır. Ayrıca daha sonraki dönemde İstihkâm Albay Lake, Yüzbaşı Thompson ile İran'daki İngiliz Büyükelçiliğinden sivil görevli Churchill de Kars'ta emrine girecektir. İngiliz diplomatik raporlarında anılan dönemde Williams'ın rütbesi albay olarak ifade edilmesine rağmen Doktor Sandwith kendisinden general olarak bahsetmektedir. ${ }^{33}$

Williams Kars’ta kendisini sadece bir danışman olarak görmedi. Maiyetindeki Doktor Sandwith zaten iki yıl sonra yayınlayacağı hatıralarının künye sayfasında zaten Kars Garnizonunun Williams'ın emir komutasında (under General Williams) olduğunu ileri sürecektir. Dahası bizzat Williams'ın kendisi 1856 yılında kamuoyuna açık yaptığ 1 konuşmalarda Kars'taki ordunun kendi komutası altında olduğunu ifade etmekte bir sakınca görmeyecektir. ${ }^{34}$ Batı kamuoyunda da daha savaş sürerken Williams'ın Kars'ta Osmanlı kuvvetlerine komuta ettiği yönünde algı bilinmektedir. ${ }^{35}$

Kars'ta göreve başlayan Albay Williams, vakit kaybetmeden birlikleri denetledi, birliklerin sağl1k ${ }^{36}$, beslenme ve giyinmesinde önemli aksaklıklar yanında kâğıt üzerinde görülen birlik mevcutlarının fiili mevcutlardan yüksek gösterildiği ve bunun da yüksek rütbeli subay ve generaller için bir yolsuzluk kaynağı olduğu kanaatine vard1 ${ }^{37}$ Dönemle ilgili birçok kaynakta

31 Papers Relative to, age, s. 2.

32 Lake, age, s. 5-7.

33 Humpry Sandwith, A Narrative of The Siege of Kars The Six months Resistance by The Turkish Garrison Under General Williams to The Russian Army, (London: John Murray, 1856), s. 130. Williams'1n rütbesi diplomatik yazışmalarda Aralık 1854’ten itibaren tuğgeneral olarak ifade edilmektedir. Papers Relative to, age, s. 60. Doktor Sandwith, muhtemelen maiyetinde bulunduğu subayın taşıdığ1 rütbesinin çok üzerindeki nüfuzuna işaret etmek istemektedir. Doktor aynı günlüğünde (s. 274) 1855 Eylül'ü başlarında firarilerin yakalanmasını sağlayana Garnizon Komutanı 500 kuruş ödül verirken danışman İngiliz generalinin 2000 kuruş mükâfat vereceğini ilan ettirdiğini yazmaktadır. Diğer taraftan Genelkurmay Başkanlığının tercüme edip yayınladığı itibarı yüksek bir eserde de Albay (daha sonra General) Williams'ın Anadolu Ordusunda yüksek seviyede karar verici gibi olduğundan bahsedilmektedir. Allen ve Muratoff, age, s. 79.

34 George Kmety, A Narrative of The Defence of Kars on 29th September 1855, (London: James Ridgway, Piccadilly, 1856), s. 8.

35 Marx, age, s. 590.

36 Mustafa Zarif Paşa Anadolu Ordusu müşirliğini teslim aldığı gün (nizami) asker mevcudunun 17.000 olduğunu bunun da 11.000'nin hasta halde bulunduğunun kendisine rapor edildiğini söylemektedir. Ordu Müşiri göreve başladığında hastalıktan vefat eden asker sayısının günlük 50 olduğunu ifade etmektedir. Karal, age, s. 485.

37 Papers Relative to, age, s. 41, 47, 50-51, 63, 69, 80, 108-109; Sandwith, age, 130-132. İncelediğimiz dönemde Osmanlı Bahriyesinde Müşavir Paşa unvanıyla görev yapan başka bir İngiliz Amiral Slade ise anılarında Williams’ın çevresindeki Osmanlı karşıtı Ermeni tercümanların yönlendirmesi ile yüksek 
işaret edilen yolsuzluklarla ${ }^{38}$ mücadele gerekçesiyle nüfuzunu kullanarak üst seviye makam sahiplerini değiştirmeye çalıştı. Bu çerçevede Anadolu Ordusu komutanı Zarif Mustafa Paşa azledilecektir. ${ }^{39}$ Aynı göreve vekâleten tayin edilen Şükrü Paşa da yine Albay Williams'ın talebi üzerine İstanbul'daki İngiliz Büyükelçisinin girişimi ile görevden alınmıştır. Mehmet Vasıf Paşa yeni Ordu Komutanı olarak 21 Ocak 1855 günü Erzurum’a gelerek göreve başlamıştır. ${ }^{40}$

Yeni Ordu Komutanının işe yolsuzluğa bulaşmış yetkilileri görevden uzaklaştırma ile başlaması dikkat çekicidir. Bu sıralarda 3 Şubat 1855 günü İngiltere ile Osmanlı Devleti arasında bir sözleşme yapılarak bölgedeki Osmanlı kuvvetlerinden 20.000'inin İngiltere'nin idaresine bırakılmasına karar verilir. Bu kuvvete İngiliz subay ve generaller komuta edecektir. ${ }^{41}$ $\mathrm{Bu}$ sözleşmenin öngördüğü İngiltere’ye kuvvet devri gerçekleşmez. Zaten sağlık hizmetleri ve beslenmenin yetersizliğ ${ }^{42}$ yüzünden bir yıl içinde düşman karşısında verilen zayiatın iki katı kadar ağır bir kayıp da verilmiştir. ${ }^{43}$ Bunların dışında çok yüksek sayıda firarların yanında tüm bu zayiatı karşılamak üzere temin edilen bütünleme personel sayısı da oldukça kısıtlıdır. Bu yüzden artık Ruslara karşı Kars mihverinde bir taarruz düşüncesi tamamen gündemden düşmüş olmaktadır.

1855 Mayısına gelindiğinde Kars garnizonunda 19 nizamiye taburu, 8 redif taburu, 1 süvari alayı ile kale topları dışında 80 sahra topu mevcuttu. Zikredilen birliklerdeki 15.000 kişilik nizami orduya ilaveten Laz ve Kürt başıbozuklardan kurulan birlikler ile Kars'ta mahalli halktan kurulmuş sayıları 9.000'i bulan silahlı unsurlar mevcuttu. Erzurum'da 5.000 kişi kadar bir ihtiyat kuvveti, Ardahan ile Erzurum arasında toplam sayıları yine 5.000'e ulaşan muhtelif müfrezeler bulunuyordu. Ayrıca Bayazıd - Erzurum arasındaki Eleşkirt Vadisinde toplam 14.000 mevcutlu bir Kolordu ile Kars'a askeri anlamda bir yardımı söz konusu olmayan Batum ve civarında da 15.000 civarında bir kuvvet mevcuttu. ${ }^{44}$ Haziran ayında İstanbul'dan Kars Kalesi'nin savunma yeterliliğini tetkik için gönderilen Albay Zeki Bey, sadece topçu ve süvari için 18.000 rakamını verirken Ordu Komutanı mevcudun 35.000-40.000 arasında olduğunu ileri sürecekti. ${ }^{45}$

Ulaştırma hatlarının yetersizliği ve ikmal güçlükleri bütün bu kuvvetlerin muharebe etkinliğini önemli ölçüde etkileyecekti. Ordu için tertip edilen zahire ve erzakın vaktinde ulaştırılması da

rütbeli subayları yolsuzlukla suçladığını ileri sürmektedir. Slade, age, s. 410-411. Ama Slade satır aralarında Osmanlı siyasi, askeri ve bürokratik sisteminin iş göremez hale geldiğini de saklamamaktadır. Slade, age, s. 406-442.

38 Son yıllarda iki askeri tarihçinin yayınladığı bir eserde de anılan dönemde Kars'taki ordunun muharebe etkinliği ile ilgili olarak kötü hayat şartları, etkin bir sağlık sisteminin olmayışı, ikmal problemleri yanında yolsuzluğun personel zayiatını artırdı̆̆ını ve birliklerin her türlü taarruz kabiliyetini yok ettiğine işaret edilmiştir. Uyar ve Erickson, age, s. 166.

39 Zarif Mustafa Paşa kendisinin görevden alınması ve hapsedilmesinin sebebi olarak "vakit ve hal icabı her sözüne bakılır” İngiliz Büyükelçisi Canning’i görmektedir. Karal, age, s. 473.

40 Şahin, age, s. 136, 137.

41 Nihat Erim, Devletlerarası Hukuku ve Siyasi Tarih Metinleri, Cilt 1 (İstanbul: Türk Tarih Kurumu Basımevi, 1953), s. 325-327.

42 Genelkurmay Başkanlığının resmi savaş tarihi yayını da incelediğimiz dönemde Doğu Anadolu Ordusunda sağlık hizmetleri hemen hiç olmadığını ifade etmektedir. Hikmet Süer, Türk Silahlı Kuvvetleri Tarihi Osmanlı Devri Osmanlı-Rus Kırım Harbi Kafkas Cephesi Harekâtı (1853-1856), (Ankara: Genelkurmay Basımevi, 1986), s. 124.

43 Allen veMuratoff, age, s. 79.

44 Allen ve Muratoff, age, s. 79-80.

45 Şahin, age, s. 142. 
memurların özensizliği ve aynı zamanda işlek bir yol ve nakliye sisteminin bulunmayışı yüzünden aksayacaktır. $^{46}$

Diğer taraftan Kars ve Erzurum istikametine yönelecek Rus harekâtı için General Muravyev görevlendirilmişti. Muravyev 1828-1829 Rus Doğu Anadolu harekâtında aynı bölgede General Paskeviç'in maiyetinde görev almış tecrübeli bir subaydı. General Muravyev'in emrinde 29.000 piyade, 10.000 süvari ve 126 top çapında bir birlik oluşturulmuştu.

Rus ordusu 24 Mayıs 1855 günü Arpaçay’1 geçerek Kurudere ve Peldirvan'da ordugâh kurdu. Rus keşif kolları Kars'ın 10 km kadar doğusundaki Yahni Tepeleri işgal ettiler. Haziran ayı başında Muravyev ordugâhını Kars'ın 8 km güneydoğusunda Erzurum ve Kağızman'a giden yollara hâkim Mağaracık köyünde tesis edecektir. Rus ordusunda Kars müstahkem mevkiine karşı kullanılacak yetenekte toplar olmadığından kalenin yeteri kadar kuvvetle kuşatılması, kaleden dışarıya Osmanlı kuvvetlerinin harekât yapmasına firsat verilmemesi ve Kars'a civardan gelebilecek ikmal ve destek unsurlarına meydan verilmemesi ve etraftaki Osmanlı ikmal depolarının imhası esas alındı. ${ }^{47}$

Bu çerçevede daha 2 Haziran'da 10.000 kişilik bir kuvvet Erzurum Kars irtibatının kesilmesi için Kars'ın batısındaki Soğanlı Dağlarına sevk edilmişti. 11 Haziran'da da Kars ile kuzeydeki Ardahan arasındaki irtibatı kesen Rus birlikleri Erzurum ve Kağızman'a giden yolların da tamamen tutulmasıyla Osmanlı kuvvetlerini Kars garnizonuna kapatmış oldu.

14 Haziran'da Muravyev'in Kars'ın güneyindeki Kanlı Tabya’ya büyük çaplı kuvvetlerle saldırısı çatışmalara rağmen sonuç alıcı olmaktan uzaktı. Artık tahkimli şehre doğrudan saldırı yerine ikmal kanalları kesilmiş olan garnizonun açlık yüzünden teslimi beklenecekti. Ama Kars tabyalarına zayiat verdirici, taciz edici ve moral bozucu saldırılar gayrimuntazam aralıklarla devam edecekti.

$\mathrm{Bu}$ ara bir mukavemetle karşılaşmayan Ruslar Bardız, Yeniköy, Karaurgan ve Zivin'deki depolanmış Türk erzak ve mühimmatını imha etmişlerdi. ${ }^{48}$

Ruslar 1 Temmuz'da batıda Tahmas Tabyası karşısında, 10 Temmuz'da güneyde Kanlı Tabya ve kuzeyde Velipaşa Tabyasına doğru keşif hareketi yapmışlar ve 13 Temmuz'da Tahmas Tabya'ya doğru harekete geçmişlerdi. Sonuçsuz kalan bu girişimlerden sonra 24 Temmuz' da da güneyde Kanlı Tabya'ya taarruza geçilmişse bu da Ruslara birisi general 100 ölüye mal olmuş, başarısızlıkla neticelenmişti. ${ }^{49}$ Yukarıda zikrettiğimiz Kars Kalesi’ne yönelik Rus girişimleri dışında 29 Eylül 1855 günü yapılan büyük muharebeye kadar önemli bir saldırı hareketi olmadı.

Ancak ikmal desteği haziran ayından itibaren kesilen Kars Garnizonu için zor günler başlamıştı. Daha Kanlı Tabya'ya Rus taarruzunun püskürtüldüğü gün Erzurum'daki İngiliz Konsolosu Dışişleri Bakanlığına gönderdiği mesajında Kars çevresinde hiçbir ikmal kaynağının kalmadığını, garnizonun takviyesi için de ümit bulunmadığını yazmıştı. Konsolosa göre açlık kaçınılmazd1. ${ }^{50}$

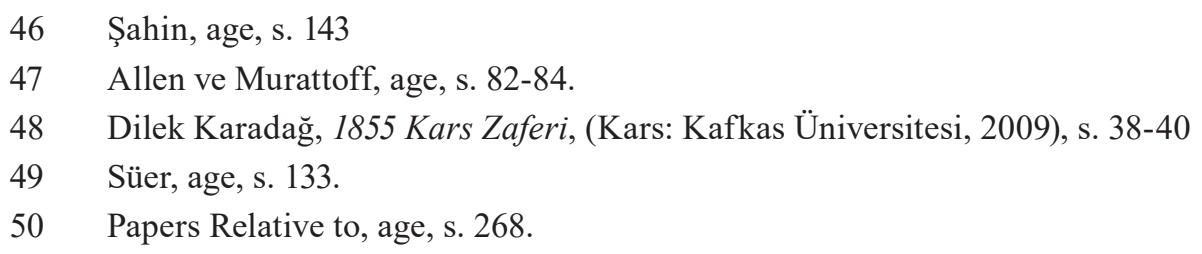


Yaklaşan açlık korkusu sadece askerler ve sivil halk için değildi. Anılan dönemde orduların süvari ve topçu sınıfları ve umum nakliye için vaz geçilmez olan at, katır ve merkep gibi binek ve yük hayvanları da beslenme sıkıntısından etkilenecektir. Daha Ağustos ayından itibaren yüzlerce at yetersiz beslenme sebebiyle ölmüştür. ${ }^{51}$ General Williams artık beslenme imkânı kalmayan 1500 atın geceleyin şehir dışına mümkün olduğunca düşmanın eline geçmeyecek şekilde bırakıldığını rapor etmiştir. ${ }^{52}$ Generalin maiyetinde bulunan Doktor Sandwith ise Oltu yolu ile şehir dişına salıverilen atların, kesilince havanını aşırı sıcaklığından ötürü etlerinin tuzlanıp saklanamayacağını söylemektedir. Ama aynı kişi beslenemeyen atların toplu olarak şehir dışına çıkarılmasından sonra bazı hayvanların kesildiğini yazmaktadır. ${ }^{53}$ Kesilen binek hayvanlarının daha Eylül başlarında personel tarafindan yenilmeye başlandığı anlaşılmaktadır.

Konsolosun bahsettiği açlık yüzünden Kars Kalesi’nden firarların artmaya başladığı anlaşılmaktadır. 4 ve 5 Eylül günü toplu firarlar üzerine yakalanan firarilerden iki nefer kurşuna dizilmiş̧ir. ${ }^{54} \mathrm{Bu}$ infaz anılan dönemde caydırıcı olmuşsa da ${ }^{55}$ general ileri haftalarda raporlarında yakalanan firarilerin kurşuna dizilmesine rağmen "baş etmemiz gereken büyük bela" firarların devam ettiğini rapor edecektir. ${ }^{56}$ Daha kötüsü beslenmenin önemli bir sorun haline geldiği, artık yıpratıcı kış şartlarının yaşandığı kasım ayında toplu firarlar olağan hale gelmeye başlayacaktır. ${ }^{57}$

Firarların esas nedeninin açlık olduğu anlaşılmaktadır. Kars Garnizonundan firar edip Erzurum'a doğru giderken Rus devriyelerince yakalanarak esir edilen 24 askerin savaş sonunda Rusya tarafından iadelerinden sonra Divan-1 harpte yapılan yargılamalarında hepsi açlık yüzünden firar ettiklerini beyan etmişlerdir. İfadelerinde bazı arkadaşlarının Rusların eline geçmemek için çatışmaya girip şehit olduklarını söyleyen firarilerin hemen hepsi Erzurum Garnizonuna ulaşarak açlıktan kurtulma niyetinde olduklarını iddia etmişlerdi. Firariler, mülazım(teğmen) gibi küçük rütbeli subaylardan da açlık sebebiyle firar edenlerin bulunduğunu ileri sürmüşlerdir. ${ }^{58}$

Beslenme yetersizliği diğer taraftan başta kolera olmak üzere bulaşıcı hastalıklar haziraneylül arasında garnizondaki personelin yüzde onunun ölümüne sebebiyet vermiştir. Başka bir kaynağa göre de muhasara altındaki Kars Kalesi'nde 10 Eylül'den itibaren kolera salgını ağır telefat verdirmeye başlamıştır. Bir ay süreyle günlük ortalama 150 asker ile 30 sivil kolera yüzünden hayatını kaybeder olmuştur. ${ }^{59}$

Ama açlık ve salgın hastalıklar Osmanlı kuvvetlerinin gücünü tükenme noktasına getirmişti. Garnizonda Ruslar hesabına istihbarat toplayanlara karşı da etkin tedbirler alındığı anlaşılmaktadır. Rus birliklerine bilgi topladığı kanıtlanan sivil halktan iki Müslüman Askeri Mahkeme tarafından idama mahkûm edilmiştir. ${ }^{60}$ İdamların çarşı meydanında infazı, İngiliz danışman heyetindeki Doktor Sandwith'in "parayı ülkesinden fazla sevenlerin zihinlerinde dehşet yarattı̆̆

51 Sandwith, age, s. 273.

52 Papers Relative to, age, s. 295.

53 Sandwith, age, s. 274-275.

54 Sandwith, age, s. 274-275.

55 General Williams'ın 7 Eylül 1855 tarihli raporu. Papers Relative to, age, s. 295.

56 Papers Relative to, age, s. 300.

57 Sandwith, age, s. 298-299.

58 Oktay Kızılkaya ve Yahya Yeşilyurt, 1855 Kars Muhasarası Firarileri Hakkında Kurulan Divan-ı Harp komisyonu, (Kars: Kafkas Üniversitesi İlahiyat Fakültesi Dergisi, sayı 1, 2014), s. 192, 194-196.

59 Kızılkaya ve Yeşilyurt, age, s. 196.

60 Sandwith, age, s. 270. Aynı günlerde casusluk yaptıkları tam olarak kanıtlamayan iki Ermeni ise hapse mahkûm edilmiştir. 
ifadesine göre muhtemel diğer düşman işbirlikçileri için caydırıcı olmuş olmalıdır. Esasen General Williams da 7 Eylül'de yazdığı raporda düşmana bilgi sızdıran iki casusun idamı ile garnizon içindeki Ruslara çalışan şebekenin dağıtıldığını rapor edecektir. ${ }^{61}$

Eylül başında şehir içindeki Ermenilerin dışarı çıkarılmasında ${ }^{62}$ iaşe sıkıntısı yanında güvenlik gerekçesi de rol oynamış olmalıdır. Zira Williams'ın heyetinden Doktor Sandwith Kars Ermenilerinin Rusların Türk Ordusu hakkındaki ihtiyaç duyacağı her türlü bilgiyi temin ettiğini yazmaktadır. Doktora göre "memleketin Ermenileri düşmanın çıkarlarına kendilerini adamıştır." Nitekim kasım ayında birisinin üzerinde Ruslara yazılmış "Az daha bekleyin. Birlikler açlıktan ölüyorlar. Paşalar birbirleriyle boğuşuyor. Yakında teslim olacaklar.” notu bulunan iki Ermeni asılarak idam edilecektir. ${ }^{63}$ General Williams'1n heyetinden İstihkâm Albay Atwell Lake de Rusların Bayazıd üzerinden Erzurum'a güneyden yaklaşma istikameti üzerindeki Köprüköy’de nüfus çoğunluğunu oluşturan Ermenilerin "açıkça Rusya destekçisi” oldukların1" anılarında zikrettiğine göre Ermenilerin Kars savunması için Ruslara istihbarat sağlayabilecekleri ihtimali yabana atılır bir iddia gibi görünmemektedir. ${ }^{65}$ Ancak Williams kendi maiyetinden farklı olarak Ermenilerin savunma için güvenlik riski oluşturmayacağı görüşündedir. ${ }^{66}$

Bu ara Sivastopol'un müttefikler tarafından ele geçirilmesi ile Ömer Lütfü Paşa'nın deniz yoluyla getirdiği kuvvetlerle Batum kuzeyinde Sohumkale'den Tiflis'e el atarak Doğu Anadolu' daki Rus kuvvetlerinin gerisini kesme girişimleri General Muravyev’i Kars'1n artık ele geçirilmesi için harekete geçmeye zorlamış görünmektedir. Bu çerçevede Ruslar 29 Eylül 1855 günü Kars’1 ele geçirmek için taarruza karar verdiler.

Kars'1 ele geçirmek için Rus taarruz planı gece yaklaşma, baskın ve hazırlıklı nihai hücum üzerine kuruluydu. Ancak Osmanlı kuvvetleri Rus birliklerinin ani hareketlenmeleri üzerine düşman saldırısına karşı koyma için gereken askeri tedbirleri alma firsatı buldular. Rus birlikleri gizlilik ve karanlık yüzünden uygun taarruz düzeni alamadılar. Bazı birlikler planlandığı şekilde Kars savunmasının hassas mevkilerine değil, yanlışlıkla savunmanın en mukavim olduğu kesimlere taarruz ettiler. Rus birlikleri birbirlerine karıştı.

Gecikme yüzünden, Rus piyadesi taarruzuna gün 1şıyınca başlayabildi. Rusların klasik yakın hücum grupları Osmanlı topçusu ve Minie tüfek atışları için mükemmel hedef teşkil edecektir. Ölümcül Osmanlı ateş gücü de kaleye yaklaşan Rus hücum dalgalarını yok edecektir. Tabyalara girmeyi başaranlar da hünerli karşı taarruzlarla püskürtüleceklerdir. Türkler subay ve erleriyle düşmanın her girişimine cesaret ve ustalıkla karşı koyabilmiştir.

\footnotetext{
61 Papers Relative to, age, s. 295.

62 Karadağ, age, s. 46.

63 Sandwith, age, s. 127, 258, 295.

64 Lake, age, s. 313.

65 Askeri tarihçiler Allen ve Muratoff da dönemle ilgili Ermenilerin Türk düşmanlığından ötürü Ruslar için istihbarat temininin zor olmadığ

66 General Williams casusluğu kanıtlanan Ermenileri münferit vaka olarak görme eğilimindedir. Sultanın gayrimüslim tebaasının Kars'ın savunmasında herhangi bir ihanetlerinin olmadığını Londra'ya rapor etmektedir. Papers Relative to, age, s. 300. Bu rapor üzerine İngiliz Dışişleri Bakanı Kars’taki Hristiyanlardan (Ermeniler) bir teki bile sadakatsizlik göstermediği için İstanbuldaki Büyükelçisine Babıali'nin haklarında "hayırhah" tavsiyelerde bulunması talimatı verecektir. (s. 303)
} 
General Muravyev, gün ortasında birliklerine geri çekilme emri vermiştir. Ruslar saldırıya katılan birliklerinin yarısından fazlasını kaybetmişlerdi. ${ }^{67}$ Muharebeler esnasında kendisi de Kars'ta bulunan Anadolu Ordusu Komutanı Vasıf Paşa, tabya içi ve dışında ve hendeklerde ölü Rus askerinin sayısını 4000 olarak rapor etmiş, Rusların götürdükleri ile bu sayının toplam 7000'e ulaştığını değerlendirerek, 100 esir ile bir kıt'a topun da ganimet olarak alındığını yazmıştır. ${ }^{68}$ Takvim-i Vekayi'de yayınlanan 3 Kasım 1855 tarihli Kars zaferi ile ilgili taltifat tebliğinde de garnizon çevresinde bulunan 6486 Rus askerinin cesedinin üç gün boyunca Osmanlı askerlerince defnedildiği ifade edilmiştir. ${ }^{69}$

Osmanlı kuvvetlerinin zayiatı ise "askerlerden 407 şehit, 443 yaralı ve Kars ahalisinden de 6 kadın, 9 âlim olmak üzere 70 şehit ve 130 yaralı olmak üzere bütün Türk zayiatı 1094 kişiyi geçmemekteydi." ${ }^{70}$ Dönem boyunca, General Williams ise muharebe sonrası raporunda Ruslara karşı "kahramanca dövüşen" Kars ahalisinden hayatını kaybedenlerin sayısını 101 olarak ifade etmektedir. $^{71}$

Osmanlı kuvvetleri; yeterli binek hayvanlarından yoksun olmaları, hastalık ve yarı açlığın yıprattı̆̆ı personel kısıtlamaları yüzünden kazandıkları ezici zaferi kalıcı bir başarıya dönüştürme imkânı bulamamışlardı.

Osmanlı kuvvetleri tarafından Ruslara karşı kazanılan 29 Eylül 1855 tarihindeki zafer moral ve motivasyon açısından kayda değer bir etki yaratmıştı. Erzurum ve İstanbul'da zaferi kutlama için top atışları yapılmıştı. ${ }^{72} 3$ Kasım 1855 günü yayınlanan taltifat iradeleriyle Anadolu Ordusu Komutanı Mehmet Vasıf Paşa, Ordu Kurmay Başkanı Abdülkerim Paşa ve General Williams'a birer murassa (altın kabzalı süslü) kılıç; sonraki iki generale ikinci rütbeden Mecidiye Nişanı verilmesi uygun bulunmuştu. Ayrıca kazanılan zaferin anısına askerlere ve halka verilmek üzere bir madalya çıkarılmasına ve muharebe boyunca "kadın ve erkeği ile" büyük fedakârlık gösteren Kars halkının savaş boyunca ve harbin bitiminden itibaren üç yıl boyunca vergi ve askerlik hizmetinden muaf tutulacağına ilişkin iradeler çıkarılmıştı. ${ }^{73}$

Ancak bu taltifat iradeleri Kars'a ikmalsizlik ve iaşesizlik yüzünden tükenme noktasına doğru düşmekte olan garnizonun acı sona yaklaşmasını durdurmaktan uzaktı. Kars Rus işgaline düşmeden taltifat yazıları şehre ulaşamayacaktı.

67 Uyar ve Erickson, age, s. 169-170. Türk Silahlı Kuvvetleri Tarihi (1853-1856), s. 135-138.

68 Şahin, age, s. 171.

69 Hakk1 Yapıc1, Takvim-i Vekayi'de Kırım Harbi (1853-1856), (Erzurum: Atatürk Üniversitesi, 1999) s. 91. Rus Komutarı General Muravyev Rus ölü sayısını Çar’a 6517 olarak rapor etmiştir. Hernon, age, s. 165.

70 Kırzıoğlu, 1855 Kars Zaferi, age, s. 148 Kars savunmasının tanınmış simalarından Macarlı İsmail Paşa (George Kmety) da ölü ve yaralı olarak Türk zayiatını 1094 olarak vermekte, muharebeden sonra gömülen Rus ölü sayısını 6500 olarak ifade etmektedir. Kmety, age, s. 44.

71 Lake, age, s. 233. "Kars’ın kadınları tabyalardaki mücahidine ekmek ve su ve fişsenk götürmek gibi hizmetlerde bulundukları cihetle o biçarelerin dahi altısı şehid olmuştur." Cevdet Paşa, Tezakir 1-12, (Ankara: Türk Tarih Kurumu Basımevi, 1953), s. 59. "Halk tahkimat, inşaat, ulaştırma işlerinde bütün olanaklarıyla orduya yardım ediyordu." Süer, age, s. 169.

72 Budak, age, s. 133.

73 Yapıc1, Takvim-i Vekayi, s. 91-97. Mili Mücadele döneminde Antep'e gazilik unvanı verilmesi ve şehrin düşüşü (1921) ile Kars taltifatı yazıları daha şehre gelmeden müstahkem garnizonun düşman eline geçmesi (1855) arasında benzerlikler ilginçtir. 
İkmal hatları kesilmiş ve açlığın pençesindeki garnizonun çıkış yolu görünmüyordu. Açlık ve hastalıklar Osmanlı kuvvetlerinin muharebe etkinliğini hızla düşürmekteydi.

Doktor Sandwith'in günlük notları Osmanlı savaş ve mukavemet yeteneğinin bitme noktasına geldiğine tanıklık etmektedir. Ekim ayının sonunda eldeki atlar süvarisini taşıyamayacak durumdadır. Bu atlar da gida yetersizliğinden kesilmeye devam edilmektedir. At eti personel için lüks tüketim maddesi olarak görülmektedir. Açlık yüzünden ölmek üzere olan askerlere at eti suyundan yapılmış çorba ilaç olarak verilebilmektedir. Kasım ayı başlarında artık elde kalan atlar, etlerinden çorba yapılmak üzere boğazlanmaktadır. Kars'ın tesliminden bir hafta öncesinde artık Doktor Sandwith'in çalıştığ 1 hastaneye su taşyyacak at da topçu ve süvarinin atı da kalmamıştır. Daha fecisi insanlar gömülmüş hayvan leşlerini çıkarıp yemeye başlamışlardı. 2000 hastanın bulunduğu hastanede günde ortalama 100 asker açlık ve hastalıktan ölmektedir. Garnizonun sadece yedi günlük erzakı kalmıştır. Küçük çocuklarını besleyemeyen kadınların yavrularını karargâhtaki subayların ayakucuna atıp "alın bu çocukları, yedirecek ekmeğimiz yok..." feryatları sarsıcıdır.

Arazi karla kaplı, geceler dayanılmaz derecede soğuktur. Giyim kuşamı iklim şartlarına göre olmayan askerler ölen arkadaşlarını üzerindeki giyecekleri almaktadır. Garnizonun Kars'1 tahliye ederek çekilmesine de maddeten imkân kalmamıştır. ${ }^{74}$ Sohumkale'ye çıkan Ömer Lütfü Paşa'nın Tiflis istikametine yürüyerek Kars önündeki Rus birliklerinin gerisini tutma planının da gerçekleşmeyeceğinin anlaşılması Kars müdafilerinde uzak bir ümit ışığı dahi bırakmamış durumdadır.

Bu durumda Anadolu Ordusu Komutanı için Kars'ın Ruslara teslim edilmesi, seçeneği olmayan bir mecburiyet haline gelmiş görünmektedir. General Williams yaverini ateşkes bayrağ 1 ile Rus karargâhına göndererek General Muraviyev ile görüşme talebini iletir. İki general arasında 27 Kasım 1855 günü Kars'ın teslim anlaşması imzalanır. Bu anlaşmaya göre redifler, başıbozuklar ve Laz gönüllüleri, doktorlar ve sağlık çalışanları gibi muharip olmayan unsurlar ve listesini General Williams'ın hazırlayacağı Macar ve diğer Avrupalı subayların evlerine dönmelerine izin verilecek ancak bunlar Rusya'ya karşı mevcut savaş boyunca herhangi bir hizmette bulunmamaya şerefleri üzerine söz vereceklerdi. Diğer subay, general ve askerler savaş esiri olarak alınacaktı. ${ }^{75}$

$\mathrm{Bu}$ çerçevede garnizondaki subay ve generallerle 8.000 nizamiye askeri esir olarak ${ }^{76}$, kaledeki 136 top ganimet olarak Rusya'ya götürülmüştür. ${ }^{77}$

Kars'ın açlık ve hastalık yüzünden artık Ruslara teslim edileceğinin anlaşıldığı günlerde yürümeye takat getirebilecek kadar sağlığı müsait asker ve Kars ahalisinden silahlı gönüllülerin kaleden çıkarak Erzurum'a gitmelerine izin verildiği anlaşılmaktadır. Bunlardan Erzurum'a ulaşabilenlerin sayısı arşiv vesikalarına göre 5.868 asker ve 1602 sivil halktan olmak üzere 7.500'e yakındır. ${ }^{78}$ Ancak Kars'ın tesliminden önce Erzurum'a çekilmek isteyenlerin bir kısmı da Soğanlı Dağlarında donarak ölmüşlerdi. Bunlardan bazılarının cesetleri düşman eline geçme endişesi ile aciliyetten defnedilmeyerek açıkta bırakılmak zorunda kalınmıştır. Bu cesetlerden 47'si, Kars

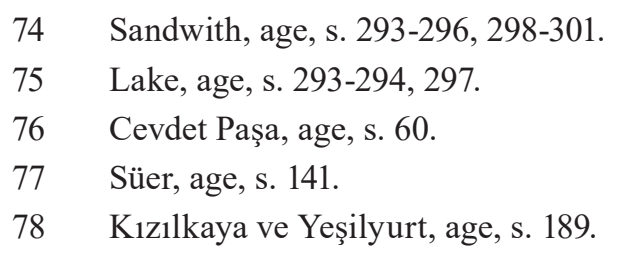


1856 yazında tekrar Osmanlı Devletine iade edilirken defnedilebilmiştir. ${ }^{79}$ Erzurum'a iklim ve sağlık şartları yüzünden ulaşamayıp yollarda kalan asker ve gönüllülerin tam sayısını ise öğrenmek mümkün olmayacak görünmektedir.

1853-1855 döneminde Kars Savunması ile ilgili cereyan eden olaylara bakıldığında da Osmanlı Ordusunun en büyük probleminin yetişmiş insan gücü noksanlığı olduğu ortaya çıkmaktadır. Bir İngiliz albay(daha sonra general) fiilen neredeyse Kars Savunmasının bir numaralı yetkilisi haline gelmiştir. Erzurum'da 1855 yılında yapılan üç tabyadan birisinin adına Williams Tabyası denilmiş olması (diğer ikisinden birisi dönemin padişahı Sultan Mecid'in, diğeri Ordu Komutanının adını taşımaktadır) İngiliz “danışmanın” hangi seviyede görüldügünü ortaya koymuştur. ${ }^{80}$ Ceride-i Havadis'te yayınlanmış olan Kars Savunması ile ilgili bir krokide ${ }^{81}$ Vilyams Paşa Tabyası, Tomson Tabyası, Tiesdeyl (Williams'ın maiyetinde bulunan Teesdale) Tabyası, Çörçil Tabyası ve Zohrap Tabyası isimlendirmeleri ${ }^{82}$ bir avuç İngiliz heyetinin Osmanlı Ordusundaki itibarlarının diplomatik nezaketin çok üzerinde olduğuna tanıklık etmektedir. Dahası yine Fahrettin Kırzıoğlu'nun 1942'de derlediği bir destanda Williams Paşa'nın açlık ve çaresizlik yüzünden Kars'1 Ruslara teslime karar verdiği ifadesi dikkat çekicidir. ${ }^{83}$ Yani dönemin bir halk aşı̆̆ının algısına göre Kars Savunmasında en yüksek makam bir İngiliz'dedir.

Savaş sonuna doğru 15 Aralık 1855'te General Williams'a daha önce verilmiş padişah Sultan Mecid tarafından verilmiş olan ikinci derece Mecidiye nişanının yeterli görülmeyerek en yüksek seviyedeki nişan olan birinci derece nişan ile değiştirilmesi ve ayrıca kendisine vezaret rütbesi verilmesi de ${ }^{84}$ Osmanlı devlet ve toplumunda her kesimde “danışman” İngiliz subayının çok yüksek bir mevkide görüldüğünü göstermektedir.

Bütün bu durum İngiltere'nin dünya devleti olması yanında Osmanlı Devleti'nde işinin ehli yeterli seviye ve sayıda subay ve general olmayışından kaynaklanmış görünmektedir. ${ }^{85}$

\section{7-1878 Savaşı}

93 Harbi diye de bilinen 1877-1878 Savaşı'nda Osmanlı savaş planı Doğu Anadolu'da Ruslara karşı Kars ve diğer birinci savunma hattındaki müstahkem kalelerin güçlü tutulmasını ve yaklaşan düşmanın imha veya püskürtülmesini öngören bir savunma stratejisini benimsemişti. Bu planın

79 Kızılkaya ve Yeşilyurt, age, s. 190.

80 Şahin, age, s. 140.

81 Kırzıŏlu, 1855 Kars Zaferi, s. 233-234.

82 İsmail Paşa da kuzeydeki Kars Tabyalarından Lake, Churchill, Thompson, Zohrab ve Teesdale tabyalarına İngiliz Tabyaları denildiğini ifade etmektedir. Adına tabya ismi verilen Thompson yüzbaşı, Churchill ise Williams'ın sekreterliğini yapan bir sivildir. Kmety, age, s. 7, 9. Zohrab ise, İngiliz heyetinin tercümanı olan Ermenidir. Sandwith, age, s. 275.

83 M F Çelik. 1855 Kars Muharebesine Dair İbrahim Adlı Bir Aşı̆̆ın Destanı, Yücel Aylık Sanat ve Fikir Mecmuası, (İstanbul: Yücel Yayınevi, 1942, sayı 84), s. 249. Belki daha ilginci Kırzığlu’nun derlediği destanı yazılmasından 87 yıl sonra yayın için kendisine gönderdiği tanınmış şair Behçet Kemal Çağlar'ın bir hastananede rastladığı Karslı bir sıhhiye çavuşunun ezberinden dinlemiş olması ve Kırzıoğlu'nun derlediği destanın bazı ibarelerini tashih etmiş olmasıdır. Bu durum İngiliz subaylarına gösterilen itibarın dar bir çerçevede kalmadığını kamuoyunca da paylaşıldığını gösterir.

84 Yapic1, age, s. 112.

85 Bu çerçevede Kırım Savaşında Fransız Ordusu Başkumandanı Mareşal Saint Arnaud Türk Ordusunda başkomutan ile askerler arasında subay ve astsubay sınıfının olmadığı ifadesi ilginçtir. Engelhardt, Tanzimat ve Türkiye, Çev. Ali Reşad, (İstanbul:Kaknüs Yayınları, 1999), s. 120. 
başarısı yeterli sayı ve nitelikte kuvvete ve birlik kaydırma için uygun yol ve intikal yeteneğine bağlıydı. Oysa bölgedeki birliklerin subay ve erleri Tuna Cephesindeki Osmanlı kuvvetlerine göre disiplin ve eğitim açısından aşağı seviyede bulunuyordu. Kars Kalesi'nin tahkimatı Kırım Harbi'nden sonra Alman mühendisler tarafından sslah edilmiş ${ }^{86}$ ve uzun menzilli modern Krupps kale topları tedarik edilmişti. ${ }^{87}$ Şehir garnizon hariç 20.000 civarında bir nüfusa sahiptir.

Ahmed Muhtar Paşa, "Dördüncü Ordu Müşiri ve Anadolu Harp Ordusu Başkumandanı" olarak 7 Nisan 1877 günü Erzurum'a geldiğinde ${ }^{88}$ Ordu'nun en iyi 26 taburunun Rumeli Cephesine alınmış olduğunu görmüştü. Kendisine Seraskerlikçe ordunun emrine girmek üzere olduğu bildirilen Kürt aşiretler ve Çerkez gönüllülerden ortalıkta eser olmadığını gördü. Ordu bölgesinde mevcutlar kâğıt üzerinde görülenlerden uzaktı. Bu çerçevede muharebenin başlamasından önce Kars'taki Kolordunun mevcudu 515 subay ve 16.585 er olarak tespit edilmişti. ${ }^{89}$ Bu kuvve 26 Piyade Taburu, 2 Süvari Alayı, 4 Topçu Taburu ve 1 İstihkâm Bölüğü halinde teşkilatlanmış bulunuyordu.

Ahmed Muhtar Paşa süratle mevcut durumu değerlendirdi. Düşmanın Kars mihveri üzerinden siklet merkezi yaparak geleceğini hesap edip bu mihver üzerindeki kuvvetlere şahsen komuta etmeye karar verdi. Zaten Kars'taki kuvvetlerin başında kendisinin Bosna' da görevliyken vazifeden el çektirdiği Hüseyin Hami Paşa gibi mizaç ve yeteneği tayin edildiği görev ile uygun olmayan birisi bulunuyordu..$^{90}$

Paşa maiyeti ile beraber yola çıkarak 19 Nisan’da Kars'a varmıştı. Yani Erzurum'dan Kars’a intikal henüz düşmanla fiili muhasamat yokken iklim şartları yüzünden dört gün sürmüştü.

Ahmed Muhtar Paşa'nın maiyetinde bulunan Mehmed Arif Bey’in gözlemlerine göre söz konusu dönemde Kars'ta istihkâmlara yerleştirilenler dışında askerin büyük çoğunluğu han, ev, ahır ve kahvehane gibi mekânlara balık istifi yı̆̆ılmıştı. Osmanlı birlikleri yeterli binek ve taşıma hayvanları olmadığından hareket kabiliyeti çok sınırlı olduğundan "kötürüm" haldeydi. ${ }^{91}$

86 İngiltere'nin Erzurum Konsolosu'nun 1869 yılında yazdığı rapora göre Kars tahkimatları yazları 1.500 ücretli, 500 gönüllü toplam 2.000 işçi ile süratle ıslah ediliyordu. Konsolosa göre iki yıl içinde tahkimatlar tamamen sağlamlaştırılmış ve yenileştirilmiş olacaktı. Turkey No. 16 (1877) Reports by Her Majesty's Diplomatic and Consular Agents in Turkey of The Conditions of The Christian of The Porte: 1868-75, (London:Harrison \& Sons, 1877), s. 21.

87 Allen ve Murattoff, age, s. 109.

88 Gazi Ahmed Muhtar Paşa, Anılar 2 Sergüzeşt-i Hayatımın Cild-i Sanisi, (İstanbul: Tarih Vakfı Yurt Yayınlar1, 1996), s.8.

89 Şadi Sükan, Türk Silahl Kuvvetleri Tarihi Osmanlı Devri 1877-1878 Osmanlı - Rus Harbi Kafkas Cephesi Harekâtı, 2. c, (Ankara: Genelkurmay Başkanlığı, 1985), s. 219. Başbakanlık Osmanlı Arşivi belgelerine göre ise Kars'ta 27.488 nefer mevcut görünmektedir. Hakkı Yapıc1, 1877-1878 Osmanl-Rus Harbi'nde Kafkas Cephesi, (Erzurum: Atatürk Üniversitesi, 2011), s. 48. Personel mevcudunda görülen büyük farkın, Kars merkezi dışındaki bazı birliklerin mevcudunun da dahil edilmesi ile aşiret süvarileri ve diğer gönüllülerin sayısının olduklarından daha yüksek beyan edilmiş olmasından doğduğu akla gelmektedir.

90 Gazi Ahmed Muhtar Paşa, age, s. 8. Hüseyin Hami Paşa’nın yerine 12 Mayıs 1877 günü Şevket Paşa tayin edildi. Ancak Şevket Paşa daha yola çıkmadan bu tayin İngiliz Büyükelçisi bu atama iptal edilmediği takdirde Babıali ile çok zorunlu yazışmalar dışında ilişkiyi kesmekle tehdit edince Şevket Paşa'nın Kars Komutanlığı gerçekleşmeyecektir. Turkey No 25 (1877), Further Correspondence Respecting The Affairs of Turkey, (London: Harrison \& Sons, 1877), s. 263-264.

91 Mehmed Arif Bey, c. 1, age, s. 102-103. 
Erzak açısından ise savaş çıkmazdan önce Rus erzak müteahhitleri Kars ve civarındaki zirai mahsulleri satın alarak muhtemel bir harekât için depolamışlardı. İşin garibi bu işler Erzurum Valisi ve 4. Ordu Komutanı Samih Paşa'nın izniyle yapılmıştı. Rusların Osmanlı ülkesinden kendi ordusunu iaşe için erzak satın alması söz konusu valinin görevden alınmasına kadar sürmüştü. ${ }^{92}$

Ruslarla savaş çıkmak üzereyken Osmanlı Ordusunda ihtiyaç duyduğu doğru ve ayrıntılı bölge haritasının bulunmadığı da anlaşılmaktadır. ${ }^{93}$

24 Nisan 1877 günü General Loris Melikov komutasındaki Rus ordusu Arpaçay’1 geçerek Osmanlı topraklarına girdi. Aynı tarihte Kars'ta İstanbul'dan Sultan Abdülhamid'in Rusya'nın resmen savaş ilan ettiğini bildiren bir telgrafı alındı. Telgrafta askeri öncelikler ve prensipler bakımından hiçbir hususa değinilmemekte askerin ve halkın hamiyet ve gayreti için çağrı yapılmaktaydı. ${ }^{94}$ Hududu aşan Rus ordusu Erzurum'a el atacak üç dügüum noktası olan Kars, Bayazıd ve Ardahan üzerine yürüdü. Bu düğüm noktalarından şüphesiz en kritiği Kars Kalesi idi. Serdar Ahmed Muhtar Paşa emrindeki yetersiz birlikleri geriye çekerek ${ }^{95}$ Kars'tan Erzurum'a giden yaklaşma yolunu Ruslara kapatmak için kaledeki birliklerin üçte biri kadar kısmıyla Soğanlı Dağları bloku üzerindeki geçitleri tutturmuş ve bu geçitlerle Kars arasındaki Zivin mevkiinde savunma mevzileri hazırlatmaya başlamıştı. Bu ara Kars Kalesi de kuşatılmıştı.

Rus kuşatması ile beraber Kars'ın sivil ahalisi kadını ve erkeği ile fedakârca askerle beraber çalışmaya başlamıştır. Mehmed Arif Bey'in gözlemleri heyecan vericidir. ${ }^{96}$ Denebilir ki halkın birinci Rus kuşatmasının ilk gününden son günü olan 8 Temmuz 1877 gününe kadarki gayreti Âşık Şenlik'in 93 Harbi Koçaklamasının "Can sağ iken yurt vermeyiz düşmana” redifinin hayata geçirilmiş fiili halidir. İngiliz diplomatik raporları Kars havalisinin sivil Müslüman halkın orduya destekleri gerekçesiyle Ruslar tarafından zulüm ve ağır hakaretlere maruz kaldıklarını haber vermektedir. Tecavüz dışında Ahmed Muhtar Paşa'nın nezdinde gözlemci İngiliz Komiseri Sör Korgeneral Arnold Kemball Kars yakınlarında kuşatma altındaki Kars'taki birliklere kendileri hakkında bilgi verdikleri gerekçesiyle Müslüman kadınların soyulup falakaya yatırıldıktan sonra çıplak vaziyette Kale'ye sürüldüklerini rapor etmiştir. ${ }^{97}$

Erzurum'a yaklaşma istikameti üzerinde kalelerden en güneydeki Bayazıd mukavemet gösterilmeden 30 Nisan gibi erken bir tarihte Rusların eline geçti. Kısa bir süre sonra da yine Erzurum güzergâhı üzerindeki Karakilise (Ağrı) kısa bir direnişten sonra Rus ordusuna teslim edildi.

Kars'ın kuzeyindeki Ardahan ise dört günlük bir kuşatma sonunda mukavemet gösterilmeden 20 Mayıs'ta Rusların eline geçti. ${ }^{98}$ Ardahan, Bayazıd ve Ağrı ele geçirildikten sonra Erzurum

92 Mehmed Arif Bey, c. 1, age, s. 95-96.

93 Mehmed Arif Bey, c. 1, age, s. 99-100. Mehmed Ali Bey'in kanaatine göre haritasılılı̆ın giderilmemesinde "şayet zabitlerimiz hudut üzerinde gezinirse, Rusya devleti kuşkulanır ve belki de devletimizden izahat ister de kim bilir başımıza ne belalar gelir." düşüncesi veya bölgenin haritasını yaptırırsa ilgili generalin görevden alınacağı endişesi rol oynamıştır.

94 Gazi Ahmed Muhtar Paşa, age, s. 25.

95 Uyar ve Erickson, age, s. 193.

96 Mehmed Arif Bey, c. 1, s. 119, 123, 124.

97 Turkey No 23 (1877), Further Correspondence Respecting The Affairs of Turkey, (London: Harrison \& Sons, 1877), s. 3,4,13,14.

98 Ardahan'ın savunma için herhangi bir hazırıllı̆ı olmadığı bilgisini Rus kuvvetlerine Ermeniler iletmiştir. 
istikametinde ilerleyen Rus kuvvetleri Ağrı ile Erzurum arasındaki Tahir Gediğinde Osmanlı kuvvetlerini 16 Haziran'da mağlup etmiştir. 21 Haziran' da Tahir' deki Rus kuvvetlerine taarruz eden Serdar Ahmed Muhtar Paşa da başarılı olamamıştır. Aynı günlerde Kars civarında da çatışmaları olduğu bilinmektedir. ${ }^{99}$

Ruslar 25 Haziran 1877 günü 24.000 kişilik bir kuvvetle Erzurum yaklaşma istikametini açmak için Zivin'deki savunma hattına taarruza geçtilerse de Ahmed Muhtar Paşa'nın başlarında bulunduğu Osmanlı kuvvetleri tarafından püskürtüldüler. Geri çekilen Rus kuvvetleri takip edilemedi. ${ }^{100}$ Ruslar 8 Temmuz'da Kars doğusuna geri çekilirken kendileriyle vatandaşı olduğu Osmanlı Devletine karşı işbirliği yapan Ermeniler de beraber geri çekilmiştir. Bu ara Kars'ın Ruslar tarafından ilk muhasarası da sonlanmıştır. Kars’’n 40 km kadar doğusundaki Başgedikler- Arpaçay hattı Kars garnizonunun yeni savunma hattı haline geldi.

Rusların Kars doğusuna çekilmeleri üzerine Soğanlı Blokunu tutan birlikler Kars'a yaklaşırken mahalli halk mutasarrıf, kadı, müftü, eşraf ve âyan başta olmak üzere büyük bir sevinçle orduyu karşılamak üzere şehrin dışına çıktı. 9 Temmuz 1877 günü Ahmed Muhtar Paşa muzaffer bir kumandan olarak Kars'a girdi komutan ve askerleri gösterdikleri sebat ve gayretten dolay1 kutladı. ${ }^{101} \mathrm{Bu}$ ara yetersizliği bilinen Hüseyin Hami Paşa’nın yerine Kars Kale Komutanlığına İstanbul'dan tayin edilen Müşir Mustafa Fazıl Paşa'ya Anadolu Ordusu Başkumandanı tarafından şehrin tabyaları gösterilerek görev değişimi yaptırıld1. ${ }^{102}$ Aynı gün İstanbul' dan gelen bir telgrafla da Ahmed Muhtar Paşa Sultan Abdülhamid ve hükümet tarafindan tebrik edildi. ${ }^{103}$

$\mathrm{Bu}$ ara Ahmed Muhtar Paşa savunma hattının güneyindeki Alacadağın kuzey yamaçlarında savunma için tertiplenme hazırlıklarını başlattı. ${ }^{104}$ Rus kuvvetlerinin 25 Ağustos 1877 tarihinde Başgedikler yakınlarındaki Kızıltepe'deki Türk kuvvetlerine saldırısı sonuçsuz kaldı. Bu başarı üzerine Ahmed Muhtar Paşa'ya Sultan tarafından “gazi” unvanı verildi. ${ }^{105}$ Ruslar 2-3 Ekim'de Yahniler'e saldırdılarsa da sonuç alamadılar. Rusların başarısız olarak geri çekilmesi İstanbul'da Yahniler Zaferi olarak kabul edildi. Gazi Ahmed Muhtar Paşa birliklerini 8/9 Ekim günü daha önce tertiplenme yapılmış olan güneydeki Alacadağ'a çekti. Rus kuvvetleri 15 Ekim'de Alacadağ'a taarruz ederek Türk birliklerini ağır bir yenilgiye uğrattılar. Gazi Ahmed Muhtar Paşa, düzenli

Allen ve Muratoff, age, s. 111.

99 İngiliz diplomatik raporlarına göre Kars yakınlarında bir çatışmadan sonra Rusların kontrolünde kalan arazideki şehitlerini almak için görüşmek üzere Kars Komutanı yaverini beyaz bayrakla bölgedeki Rus kuvvetlerine göndermek ister. Ancak Ruslar dönemin askeri teamüllerine aykırı olarak ateş açarak yaveri yaralarlar. Osmanlı Hariciyesi olayı Londra'da İngiliz Hariciyesine bildirir. Turkey No 1 (1878), Further Correspondence Respecting The Affairs of Turkey, (London: Harrison \& Sons, 1878), s. 73.

100 Uyar ve Erickson, age, 194.

101 Mehmed Arif Bey, Başımıza Gelenler, 2. c., Haz. M. Ertuğrul Düzdağ, (İstanbul: Tercüman 1001 Temel Eser, ty), s. 353-355.

102 İhtiyarlığı sebebiyle görevini yapamayan müşir paşanın yerine kısa bir zaman sonra Ahmed Muhtar Paşa Bayezid Tümen Komutanı Ferik Ahmed Fazıl Paşa’yı getirecektir. Gazi Ahmed Muhtar Paşa, age, s. 7172.

103 Rifat Uçarol, Gazi Ahmet Muhtar Paşa, (İstanbul: Filiz Kitabevi, 1989), s. 70

104 A J Schem, The War in The East Between Russia and Turkey, (New York: H S Goodspeed \& Co., 1878), s. 339.

105 Uçarol, age, s. 79. Gazi unvanının bildirildiği 1 Ekim 1877 tarihli telgrafla paşanın ayrıca yine Sultan Abdülhamid tarafından bir kılıç, iki at ve murassa Mecidiye Nişanı ile ödüllendirildiği bildirilmiştir. 
birliklerinin yarısını kaybetti. 7 general ve 252 subayla toplam 12.000 esir verildi. Çoğunluğunu başıbozukların oluşturduğu süvarilerin tamamına yakını firar etti. ${ }^{106}$

Alacadağ'daki felaketten kurtulanların bir kısmı güneye Kağızman'a, 10.000 kadarı da Kars Kalesi'ne sığındılar. Kale Komutanlığ 1 tekrar eski komutan Hüseyin Hami Paşa'ya bırakıldı. ${ }^{107}$ Gazi Ahmed Muhtar Paşa kaledeki 15.000 kadar kuvvetin üçte biri ile Soğanlı Dağları üzerindeki geçitleri tutturdu. Güney mihverinden gelecek kuvvetlerle birleşmeyi tasarladı. ${ }^{108}$

Ruslar 36.000 kişilik kuvvetle Kars'1 Alacadağ'da kazandıkları ezici zaferden sonra 16 Ekim 1877'den itibaren tekrar kuşattılar. Ruslar şehri ele geçirmek için üç aşamalı bir plan hazırlamışlardı. Buna göre önce garnizonun komutan ve subayları teslim için ikna edilmeye uğraşılacaktı. Bununla sonuç alınmazsa şehir halkı üzerinde korku ve panik yaratacak yoğun top atışlarına başvurulacak sivil halkın şehrin teslim edilmesi için askeri yetkililere baskı yapması sağlanacaktı. Bundan da sonuç alınamazsa şehri çevreleyen tabyaların en zayıf yerinden saldırı ile garnizon ele geçirilecekti.

Bu plan çerçevesinde Kale komutanı ve subayları şehri teslim etmeleri için ikna edemeyen Ruslar, mayıs ve haziran kuşatmasında başarı elde edemedikleri kayalık kuzey tabyaları hattı yerine 5 Kasım sabahı güneydeki Süvari Tabya, Kanlı Tabya ve Hafız Paşa Tabyalarının bulunduğu yedi buçuk kilometrelik cephe boyunca Kars'ı bombardımana başladılar. 40 muhasara topu ile başlayan bombardıman yukarıdaki tabyaları ve şehrin güney mahallerini hedef aldı. Şehirde yangınlar çıktı. Hafız Paşa Tabyasından Ruslara karşı taarruz yapıldı. Başlangıçta başarı kazanıldıysa kalıcı sonuç elde edilemedi. 8/9 Kasım gecesi tabya Ruslar tarafından ele geçirildiyse de karşı taarruzla püskürtüldüler.

Ruslar aydınlık bir gecede baskın şeklinde bir taarruzla Kars'ı ele geçirmeye karar verdiler. 17/18 Kasım gecesi saat 20.30'da taarruza geçtiler. İhtiyatlar dışında Rus kuvvetleri 7 kola ayrıldı. Bu kollardan ikisi kuzeyden, güneybatıya kadar olan cephede gösteriş taarruzu yapacak, diğer kollar güney ve güneydoğudaki tabyaları ele geçirip şehre doğru ilerleyip Kars Çayını geçip kuzeydeki tabyaları ve İç Kaleyi ele geçireceklerdi. Taarruz bu çerçevede icra edildi. Kars'ın çevresindeki tabyalardan en fazla güneydeki Kanlı Tabya ve batıdaki Çim Tabya direndi. Kanlı Tabya 03.00'te düştü. Çim Tabya'da 6. Alaydan bir Tabur ile bir Redif Taburuna komuta eden bir "Bimbashi" sabah ortalık aydınlanıncaya kadar "en cesur ve sebatkâr mukavemet" göstererek Ruslara ağır kayıp verdirdi. İngiliz diplomatik raporlarına göre bu subay ve iki tabur hezimetle biten Kars savunmasının "şerefli bir istisnasıydı."109 Bazı tabyalar baskınla mukavemetsiz olarak

106 Çakın ve Orhon, age, s. 485-486. Ruslar Alacadă̆ Muharebesinde 18.000 esir aldıklarını ileri sürmüştür. Schem, age, s. 346.

107 Uçarol, age, s. 86-87.

108 Çakın ve Orhon, age, s. 486. Uyar ve Erickson, age, s.195 Allen ve Muratoff, age, s. 173-174.

109 David Gillard, British Documents on Foreign Affairs: Reports and Papers From The Foreign Office Confidential Print, Part I, Series B, vol. 4 The Ottoman Empire and The War With Russia 1877-1878, (Universitiy Publications of America, 1984), s. 128. Batum'daki İngiliz Askeri Ataşe Yardımcısı vazifesini şerefle yapan binbaşının adını tespit etmeye çalışacağını da ifade etmektedir. Çim Tabya'da kahramanlık gösteren bu subay, Mehmed Arif Bey’in yazdıklarına göre Tabya komutanı 4. Süvari Alay Komutanı Yarbay Kürt Yusuf Beydir. Ancak resmi bir yayına göre de aynı tabyada görevli bir de Binbaşı Yusuf Bey vardır. Binbaşı Yusuf da Of Mustahfaz Tabur Komutanıdır. Kahramanlık gösteren Çim Tabya'daki kişi bu iki Yusuf Bey'den birisidir. Belki her iki subay da kahramanlık göstermiştir. Mehmed Arif Bey, Başımıza Gelenler, c. 3, Haz. M. Ertuğrul Düzdağ, (İstanbul: Tercüman 1001 Temel Eser, ty), s. 832; Sükan, age, s. 174. 
Ruslara teslim oldu. Yarım saat sonra Kars Çayının güneyindeki tabyaların tamamı Rus ordusunun eline geçmişti. Sabaha karşı saat 04.30'da İç Kale'de teslim olunca yapılacak bir şey kalmamıştı. Kale Komutanı Hüseyin Hami Paşa 15 tabur kadar askerle kaleden çıktıysa da bunların büyük bir kısmı Rus süvarileri tarafından ele geçirilmişti. Kale Komutanı 200 süvari ile Oltu’ya gelmişti. ${ }^{110}$ Türk kayıpları esirler ve yaralılar hariç 5.000 olmuştu.

18 Kasım 1877 günü Kars’1 ele geçirmiş olan Ruslar. 5 general ile 10.000 askeri esir, 300 civarında top ve geniş ölçüde mühimmat ve erzakı ganimet olarak aldılar ${ }^{111}$ Rusların kaybı ise subaylar dâhil 2.800 gibi çok düşük seviyede kalmıştı. Kars'ın ele geçirilmesi ile serbest kalan Rus kuvvetlerinden 15.000 hemen aynı gün öğleden sonra Erzurum önündeki kuvvetlerine katılmak için harekete geçirilecekti. ${ }^{112}$ Ruslar şehri teslim alınca daha önceki Kars'1 teslim aldıklarında yaptıkları gibi yine bütün başıbozukları evlerine yolladılar.

Şehrin Rusların eline geçmesinden sonraki manzara görgü şahitlerinin aktarımı ile İngiliz diplomatik belgelerine yansımıştır. Majestelerinin Batum'daki askeri ataşe yardımcısı yüzbaşının raporuna göre Rus askerlerine şehrin Ermeni Mahallesi hariç Kars'1n üç gün süreyle yağma izni verilmişti. Ruslar yağma yaparken gözcülüklerini Ermeniler yapıyorlardı. Yağmacılar beraberlerinde götüremeyecekleri değerli her şeyi imha ediyorlardı. Rapora göre yağmacıların en belirginleri Rusya Çerkezleriydi. İnsanlar aranarak üzerlerindeki para ve değerli şeylerin hepsi gasp edilmişti. Ayrıca şehirde hükümete ait yarısı kağıt yarısı madeni 2.000.000 kuruş paraya da el konulmuştu. ${ }^{113}$

Hastanede 4.000 hasta ve yaralı bulunuyordu. Günlük ortalama kırk ellisinin hayatını kaybettiği dizanteriolan hasta ve yaralıdan yürümeye takati olanlar üç gün boyunca kaçırtılmışlard1. ${ }^{114}$ Yürümeye gücü yetmeyenler hastaneye geri döndüklerinde hasta yataklarında soyuldular. Hastanedeki bütün ilaç şişeleri kırılarak imha edildi. Ölmek üzere olan hasta bir albayın altından üzerinde yattığı yatak alınacaktı. İngiliz askeri ataşe yardımcısı iki üç saat sonra can verecek albayın dul eşi ve çocuklarının Batum'a geldiğini de yazmaktadır.

Kars'tan uzaklaştırılan hasta ve yaralılar buz tutmuş yollar üzerinden Erzurum'a ulaşmaya çalıştılar. Erzurum'da hastanede Kızılay nezdinde görev yapan İngiliz Doktor Ryan, Gazi Ahmed Muhtar Paşa'nın kendisine Kars'tan çıkarılan hasta ve yaralılardan Erzurum'a sadece 317'sinin ulaşabildiğini söylediğini aktarmaktadır. Doktor Ryan Erzurum'a ulaşabilenlerin bir kısmının ayak parmaklarını kaybettiklerini yazmaktadır. ${ }^{115}$ Anlaşılan Kars'tan atılan hasta ve yaralıların

110 Mehmed Arif Bey, 3. c, s. 832-833.

111 Sükan, age, s. 171-180. Çakın ve Orhon, age, s. 488. Allen ve Muratoff, age, s. 187-194. Uyar ve Erickson, age, s.197. Gazi Ahmed Muhtar Paşa, age, s. 238-242.

112 George B McClellon, Capture of Kars and Fall of Plevna, (The North American Review, vol. 126, 1 Jan 1878), s. 143, 144.

113 British Documents on Foreign Affairs, age, s. 128.

114 Ahmed Muhtar Paşa’nın Seraskerliğe telgrafına göre Rusların Kars’taki hasta ve yaralıların sayısı 5.0006.000 arasındaydı. Osmanlı Hariciyesi, dönemin konuyla ilgili Cenevre Sözleşmesinin VI. Maddesine aykırı gördüğü Rusların bu gayriinsani uygulamasını diplomatik kanaldan protesto etmiştir. Turkey No. 1 (1878), s. 543, 550.

115 Charles S Ryan, Under The Red Crescent, (New York:Scribner's Sons, 1897), s. 333. Gazi Ahmed Muhtar Paşa'nın maiyetinde bulunan Mehmed Arif Beyin kanaatine göre Rusların hasta ve yaralıları ellerine birer ruble para ile bir ögün yiyecek vererek hasta ve yaralıları Kars'tan dışarı çıkarmasının sebebi "Bizim hastahanelerin mevcudunu çoğaltıp telâşımızı artırmak ve ahlâkı bozulmuş, hayatından 
talihi, 1855 Kasımında aynı buzlu yollardan Erzurum'a yürüyen hasta kaderdaşlarından daha iyi olmamıştı.

Kars'ın 22 y1l sonra tekrar Ruslar tarafından ele geçirilmesi Mehmed Arif Bey’ göre “devlet ve milletin vücudunda rahneler açtı".116 Kars'ın kaybı Ruslara karş1 Anadolu'nun savunmasında açılmış büyük bir gedik oldu. Oysa Kars savunması 1855 yılındaki savunmaya göre personel sayısı, etkili toplar, silah ve teçhizat ile erzak açısından çok daha uygun şartlarda yapılıyordu. ${ }^{117}$

"Kars gibi metin ve rasin olan düşmana pek çok telefat ve zayiat verdirmedikçe teslimi gayr-i kabil bulunan istihkâmatın böyle kolaylıkla düşman tarafindan istilasına” sebep olan şartlar hakkında Kurmay Yarbay Atıf Bey tarafından bir rapor hazırlandığı bilinmektedir. ${ }^{118}$ Atıf Bey 21 Kasım 1878 tarihinde tamamladığı raporunda ilgili birlik komutanlarının taktik ve idari çerçevede kimlik ve tarih zikrederek yaptıkları önemli hataları 16 madde halinde sıralamıştır. Rapor sorumluların Anadolu Ordusu Divan-1 harbi tarafından yargılanması teklifi ile son bulmaktadır. Raporda talep edilen yargılamanın yapılıp yapılmadığı tespit edilememiştir.

\section{Değerlendirme}

50 yıl içinde üç defa düşman eline geçmiş olan Kars'ın savunma zafiyetinin sadece münferit şahsi ihmallerden kaynaklanmadığı anlaşılmaktadır. Osmanlı siyasi, sosyal ve askeri sisteminde şahsi ihmal ve yetersizliklerden ötesinde daha derinlerde bünyevi sebepler bulunduğu ileri sürülebilir.

Bu sebeplerin başında 19. yüzyıl boyunca Osmanlı İmparatorluğu'nun istikrarlı ve kendine yeterli bir askeri yapılanma gerçekleştiremediğine işaret edilmelidir. Mektepten yetişmiş yeterli bir subay ve general kadrosu noksanlığı her zaman kendini hissettirmiştir. 1854-1855 y1llarında Doğu Anadadolu'daki 4. Ordu Cephesindeki Harbiye mezunu subay sayısı sadece 14 idi. Bunların da amirlerinin ve diğer subayların baskılarıyla görev yapamaz hale getirildiğini İngiliz askeri danışmanların yazdıklarından öğrenmekteyiz. ${ }^{119}$ Aynı savaşta Macar ve Polonya muhaciri çoğu Müslüman olmuş subay ve generallerle Avrupa'dan sözleşmeli olarak getirilmiş subaylarla ${ }^{120}$ bu açığı kapatabilmek mümkün olamamıştır.

usanıp bıkmış birtakım adamları mevcut askerimizin içine sokup, onların da zihnini ve ahlâkını bozmak, erzak ve levâzımat sarfiyatımızı da çoğaltmak idi. Kendisi de beyhûde yere bu kadar işe yaramaz adamı beslemek külfetinden kurtulmak istediğinden şüphe mi vardır!” Mehmed Arif Bey, 3. c, s. 859.

116 Mehmed Arif Bey, c. 3, s. 835.

117 İngiliz diplomatik raporlarında bazı Rus subaylarının Kars'ın bu kadar kolay ele geçirilmesine şaşırdıkları ifade edilmektedir. Aynı yazışmalarda Batum'a sığınan Kars Mutasarrıfı'nın şehirde 6 ay yetecek erzak bulunduğu ifadesi ilginçtir. British Documents on Foreign Affairs, age, s. 128.

118 Kaymakam Atıf, 1293 Senesinde Kars'ın Sukutu Sebepleri Hakkında Rapor, (İstanbul: Askerî Mecmua Tarih Kısmı, 63 numrolu Askerî Mecmuaya mülhak olarak neşredilmiştir, sayı 4, Kanun-u sâni 1926), s. $1-19$.

119 Atwell, age, s. 61-62. Cumhuriyet döneminde Harp Okulları 4 yıllık mezunlarını ilk defa 1978 yılında vermişlerdi. Bu satırların yazarı Kara Harp Okulu'ndan 1982 yılında subay çıktığında aynı okuldan 2 ve 3 yıllık eğitimle mezun olan bazı subayların 4 yıllık mezunlara karşı nasıl kaba bir önyargı ile konuştuklarını hatırlamaktadır.

120 1877-1878 Harbinin ilk safhasında Ordu Komutanı olan Müşir Mustafa Zarif Paşa'ya göre 4. Orduda 20’nin üzerinde yabancı subay mevcuttu. Karal, age, s. 486. 
Mevcut Osmanlı subayları arasında işine vakfı kendisini görevine adamış hakkıyla birliğine hâkim olanların sayısı yok denecek kadar az görünmektedir. İngilizlerin rapor ve hatıraları bu subaylar hakkında ağır ithamlarla doludur. ${ }^{121}$ İngilizlerin ve Fransızların ${ }^{122}$ Osmanlı Ordusuna genel olarak sempati beslemedikleri ve genellikle Türklere düşman Ermeni tercümanlar tarafından yönlendirildikleri iddia edilebilirse de döneminin Osmanlı subay kitlesinin subaylık için gerekli mesleki formasyondan uzak olduğu söylenebilir. ${ }^{123}$ Subay kitlesi için bahse konu yetersizliğin artık alaylı subayların devre dışı bırakıldığı 1912-1913 Balkan Harbi sonrasında da sürdüğü aktarılmaktadır. Birinci Dünya Harbi'nde görgü tanı̆̆ 1 bir subayın ifadesiyle bu yetersizlikler bir huy olarak yüzyıllardır iliklere işlemişti. ${ }^{124}$

İncelediğimiz dönemde general yetersizliği subay yetersizliğinden daha ileri safhadadır. 1877-1878 yılı Doğu Anadolu harekâtı için Başkumandan Gazi Ahmed Muhtar Paşa'nın elini kolunu bağlayan maiyetinde mektepli general bulunmayışıdır. Mevcut generaller ise genellikle bir kısmı okuma yazma bilmeyen alaydan yetişme bir kısmı ise bölgede aşiret ve eşraf nüfuzu ile generallik ve makam verilmiş yetersiz kimselerdi. Başkumandan bunları görevden alamıyordu. Görevden alsa bile yerine tayin edecek kimse bulamıordu. 1828 ve 1853-1855 dönemi için de aynı şeyler söylenebilir.

Subay ve general zaaflarından hemen sonra erlerin durumuna işaret edilmelidir. Temel sorun etkin bir askere alma düzeninin kurulmamış olmasıdır. Askere alma sisteminin bütün imparatorluk coğrafyasında adil ve her kesim için geçerli esasların olmayışı kaynak açısından bir daralma yaratmıştır. Bu çerçevede askerlik yükümlülüğü daha ziyade imparatorluğun Türkçe konuşan bölgelerinin yükü olarak uygulanmıştır. Aşiret gönüllüleri, muavene (yardımcı), birlikler, başıbozuklar disiplinden uzak, kriz anlarında kolayca dağılan ve firara yatkın yapıları ile ordu için bir zafiyet alanı oluşturmuştur. Yağma, çapul, tecavüz gibi profesyonel askerliğin asla müsamaha edemeyeceği eylemler de bu tarz düzensiz birliklerden beklenen muharebe etkinliğini hemen hemen yok etmiş gibidir. ${ }^{125}$

Subaylarla erler arasında astsubay sınıfının mevcut olmayışı da bir diğer noksanlık olarak ifade edilmelidir. Erler açısından düzenli birlikler için eğitimsizlik önde gelen bir zaaf alanıdır. İaşe,

121 Mesela askeri görevlerin yapılmasına engel olacak seviyede içkiye düşkünlüğün rütbe yükseldikçe arttı̆̆1 ifadesi dikkat çekicidir. Konu ile ilgili 1854-1855 yılarına ait İngiliz diplomatik belgeler koleksiyonunda sayılamayacak kadar kötü örnekler zaman, mekân ve isim bildirilerek aktarılmıştır. Bkz. Papers Relative to...

122 Bkz. Engelhard, age, 122-124. Saint-Priest, La Turquie, son governement et ses armees pendant la guerre d'Orient, (Paris: Revue des Deux Mondes, 27.c, 1860), s. 402-434, 608-635.

1231855 savunması sırasında bir tabyada İngiliz danışmanın sivil sekreteri Churchill'in Osmanlı topçu bataryasının sevk ve idare etmesi ordudaki yetişmiş personel açığını göstermiş olmalıdır. Atwell, age, s. 202.

124 Ziya Yergök, Sarıkamış'tan Esarete, Haz. Sami Önal, (İstanbul: Remzi Kitabevi, 2005), s. 124. "Teğmeninden kolordu komutanına kadar subaylarımızda görev aşkı yoktu. Namus. Şeref ve izzet-i nefis duyguları noksandl. Muharebe demek düşmanı yenme yollarını aramak ve gerektiğinde bu uğurda ölmek seve seve kan akltmak demektir. Bizim subay arkadaşlar "dostlar şehit, biz gazi," diyerek mümkün olduğu kadar kaçamak yolu anyorlardl, [Subayların] cahilleri, ahlaksızları çoktur, cesur ve fedakârları pek azdır. "Yergök, age, s. 124, 127.

125 Kırım Savaşına ilişkin yazılmış olan bir monografide başıbozukların sivil halka saldırıları ve davranışları 19. Yüzyılın son çeyreğinde Ermeni meselesinin ortaya çıkmasının ana sebebi olmuştur. Candan Badem, The Ottoman Crimean War (1853-1856), (Leiden-Boston: Brill, 2010), s. 408. 
sağlık, barınma, giydirme ve teçhizat açısından da dönemin ekonomik buhranlarının derinleştirdiği sıkıntılar bilinmektedir. Ama bütün bunlara rağmen er sınıfı, iyi sevk idare edildiği zaman sabrı, tahammülü, kanaatkârlığı ile görevini layıkıyla yapabilmektedir. ${ }^{126}$ Ayrıca Kars ve civarındaki mahalli halkın elinden geldiğince, bazen büyük fedakârlıklarla Ordunun düşmana karşı harekâtına destek verdiği açıktır.

Bütün bu işaret ettiğimiz hususları toparlayacak olursak dönem boyunca teçhizat, iaşe ve ibate problemlerini küçümsemeden başat faktör olarak "insan malzemesi zafiyetinin" 127 cepheler ve her çeşit harekâtta kendini gösterdiğini ifade etmeliyiz. Bu zafiyet çoğunlukla ekonomi ve teknolojideki sıkıntılardan daha fazla olumsuz gelişmenin tetikleyicisi olmuş gibidir. Sistemin uygun şekilde işleyişini engelleyen ve yavaşlatan olgulara günübirlik öteleyici tedbirler dışında hal tarzı bulucu iradenin yokluğu hemen her şeyi derinden derine çürüten bir sürecin işlemesine ortam sağlamış görünmektedir.

Diğer taraftan Türkiye'de tarih yazımında insan kalitesi ile ilgili kurumsal zaaf alanlarının yeterince incelenmediğini söyleyebiliriz. ${ }^{128}$ İş daha ziyade, kaybedilen savaşlar içinde kazanılmış ama nihai sonuca etkisi olmamış muharebelerin öne çıkarılması ile popüler bir hamaset çerçevesinde kalmıştır. ${ }^{129}$ Askeri tarihi incelemesi gereken kurumlar henüz "bürokratik küçük memur zihniyeti" kalıplarının dışında kurumsal ve yapısal analizler ortaya koyamamışlardır. ${ }^{130}$

Şüphesiz incelediğimiz 50 yıllık dönemdeki Kars savunmalarında askeri harekâtın yürütülmesi ile ilgili zaafların dönemin Osmanlı İmparatorluğu'nun devlet ve toplum yapısından kaynaklandığını da ifade etmemiz gerekir.

\section{Kaynakça}

Ahmed Muhtar, 1244-45 [1828-29] Türkiye-Rusya Seferi, Cild-i evvel, (Ankara: Büyük Erkân-1 Harbiye Reisliği, 1928)

Allen, W E D-Muratoff, Paul, 1821-1921 Türk - Kafkas Sınırındaki Harplerin Tarihi, (Ankara: Genelkurmay Basimevi, 1966)

Baddeley, John F, The Russian Conquest of the Caucasus, (London: longmans, 1908)

Badem, Candan, The Ottoman Crimean War (1853-1856), (Leiden-Boston: Brill, 2010)

126 1854-1855 İngiliz askeri danışman heyetinde Albay Atwell Lake, anılarını topladığı kitabın ithaf sayfasında "Çetin zamanlarda Türk askerinin cesaret ve dayanıklı̆̆ının kaydı" notunu koymuştur. Lake, age.

127 Şahsi çıkarının her şeyin üstünde tutma, işini bilmeme, cehalet ve kendini geliştirmeme ve yolsuzluk gibi arızalar kast edilmektedir.

128 19. Yüzyılın büyük devlet adamı, hukukçu ve tarihçisi Cevdet Paşa 1855 Kars savunması ile ilgili ölçülü bir dille kurumsal ve yapısal zaaflara işaret edebilmiştir. Cevdet Paşa, age, s. 59.

129 Sonunda Kars'ın Ruslara teslimi ile sonuçlanan 1853-1855 Kars Savunması için son dönemde yaptırılmış bir yüksek lisans tezinin adı, 1855 Kars Zaferi'dir. Karadağ, age. Rahmetli Prof. Dr. Fahrettin Kırzıoğlu'nun 1955 yılında hazırladığı eserin adı da yine 1855 Kars Zaferi'dir.

1302011 yılında, Balkan Harbine dair tarafımızdan sadece açık kaynaklara dayanarak hazırlanan bir tebliğin, dönemin general ve subaylarındaki mesleki ve moral yetersizliklere de işaret ettiği için ATASE Daire Başkanlığınca Türk Silahlı Kuvvetlerinin itibarını sarsıcı bulunduğu için uluslararası akademik bir toplantıda sunulmasına mani olunmuştur. 
Bnb. İzzet, İstiklal Mücadelesinde Kars Müstahkem Mevkiine Yapılan Taarruz ve $\mathrm{Bu}$ Taarruzdan Alınan Dersler, Askerî Mecmua, 49. Cilt, Nisan 1931, say1 80

Budak, Mustafa, 1853-1856 Kırım Savaşı’nda Kafkas Cephesi, (İstanbul: İstanbul Üniversitesi, 1993)

Cevdet Paşa, Tezakir 1-12, (Ankara: Türk Tarih Kurumu Basımevi, 1953)

Çelik, M F. 1855 Kars Muharebesine Dair İbrahim Adlı Bir Aşı̆̆ın Destanı, Yücel Aylık Sanat ve Fikir Mecmuası, (İstanbul: Yücel Yayınevi, 1942, sayı 84)

Çakın, Naci-Orhon Nafiz, Türk Silahlı Kuvvetleri Tarihi III. Cilt, 5nci Kısım (1793-1908), (Ankara: Genelkurmay Basımevi, 1978)

Çakın, Naci, Türk Silahlı Kuvvetleri Tarihi, c. 3, 5nci Kısım Eki Osmanlı-Rus Harbi (18281829) Etüt, (Ankara: Genelkurmay Basımevi, 1978)

Engelhardt, Tanzimat ve Türkiye, Çev. Ali Reşad, (İstanbul:Kaknüs Yayınları, 1999)

Erim, Nihat, Devletlerarası Hukuku ve Siyasi Tarih Metinleri, Cilt 1 (İstanbul: Türk Tarih Kurumu Basımevi, 1953)

Gazi Ahmed Muhtar Paşa, Anılar 2 Sergüzeşt-i Hayatımın Cild-i Sanisi, (İstanbul: Tarih Vakfi Yurt Yayınları, 1996)

Gillard, David, British Documents on Foreign Affairs: Reports and Papers From The Foreign Office Confidential Print, Part I, Series B, vol. 4 The Ottoman Empire and The War With Russia 1877-1878, Universitiy Publication of America, 1984

Hernon, Ian, Blood in The Sand, (Sparkford: Sutton Publishing, 2001)

Karadağ, Dilek, 1855 Kars Zaferi, (Kars: Kafkas Üniversitesi, 2009)

Karal, Enver Ziya, “Zarif Paşa'nın Hatıraları 1816-1862”, Belleten, c. 4, No. 16, 1. Teşrin 1940

Kaymakam Atıf, 1293 Senesinde Kars'ın Sukutu Sebepleri Hakkında Rapor, (İstanbul: Askerî Mecmua Tarih Kısmı, 63 numrolu Askerî Mecmuaya mülhak olarak neşredilmiştir, sayı 4, Kanun-u sâni 1926)

Kırzıoğlu, M Fahrettin, 100. Yıldönümü Dolayısıyla 1855 Kars Zaferi, (İstanbul: Iş1l Matbaas1, 1955)

Kırzıoğlu, M Fahrettin, Kars Tarihi, c. 1., (İstanbul: Işı1 Matbaası, 1953)

Kızılkaya, Oktay-Yeşilyurt Yahya, 1855 Kars Muhasarası Firarileri Hakkında Kurulan Divan-ı Harp komisyonu, (Kars: Kafkas Üniversitesi İlahiyat Fakültesi Dergisi, say1 1, 2014)

Kmety, George, A Narrative of The Defence of Kars on 29th September 1855, (London: James Ridgway, Piccadilly, 1856)

Koch, Karl Emil Heinrich, Reise im Pontischen Gebirge und Turkischen Armenien, (Weimar: 1846)

Kop, Yaşar, 1828-1829 Osmanlı-Rus Savaşı'nda Kars ve Çevresi, (Erzurum: Atatürk Üniversitesi, 1999) 
Lake, Atwell, Narrative of The Defence of Kars - Historical and Military, (London: Richard Bentley, 1857)

Marx, Marx, The Eastern Question A Reprint of Letters written 1853-1856 dealing with the events of the Crimean War, (London: Swan Sonnenschein and Co. Limp, 1897)

McClellon, George B, Capture of Kars and Fall of Plevna, (The North American Review, vol. 126, 1 Jan 1878)

Mehmed Arif Bey, Başımıza Gelenler, c. 1, (haz.) M. Ertuğrul Düzdağ, (İstanbul: Tercüman 1001 Temel Eser, ty)

Monteith, W, Kars and Erzeroum with campaigns of Prince Paskiewitch in 1828 and 1829, (London: Longman, 1856)

Papers Relative to Military Affairs in Asiatic Turkey and the Defence and Capitulation of Kars, (London: Harrison and Sons, 1856)

Ryan, Charles S, Under The Red Crescent, (New York:Scribner's Sons, 1897

Sandwith, Humpry, A Narrative of The Siege of Kars The Six months Resistance by The Turkish Garrison Under General Williams to The Russian Army, (London: John Murray, 1856)

Saint-Priest, La Turquie, son governement et ses armees pendant la guerre d'Orient, (Paris: Revue des Deux Mondes, 27.c, 1860)

Schem, A J, The War in The East Between Russia and Turkey, (New York: H S Goodspeed \& Co., 1878)

Slade, Adolphus, Turkey and The Crimean War A Narrative of Historical Events, (London: Smith Elder and Co., 1867)

Süer, Hikmet, Türk Silahl Kuvvetleri Tarihi Osmanl Devri Osmanl-Rus Kırım Harbi Kafkas Cephesi Harekâtı (1853-1856), (Ankara: Genelkurmay Basımevi, 1986)

Şadi Sükan, Türk Silahlı Kuvvetleri Tarihi Osmanlı Devri 1877-1878 Osmanl -Rus Harbi Kafkas Cephesi Harekâtı, 2. c, (Ankara: Genelkurmay Başkanlığı, 1985

Şahin, Hasan, 1855 Erzurum Harekâtı, (Erzurum: Atatürk Üniversitesi, 1995)

Turkey No 1 (1878), Further Correspondence Respecting The Affairs of Turkey, (London: Harrison \& Sons, 1878)

Turkey No. 16 (1877) Reports by Her Majesty's Diplomatic and Consular Agents in Turkey of The Conditions of The Christian of The Porte: 1868-75, (London: Harrison \& Sons, 1877)

Turkey No 23 (1877), Further Correspondence Respecting The Affairs of Turkey, (London: Harrison \& Sons, 1877)

Turkey No 25 (1877), Further Correspondence Respecting The Affairs of Turkey, (London: Harrison \& Sons, 18779

Uçarol, Rifat, Gazi Ahmet Muhtar Paşa, (İstanbul: Filiz Kitabevi, 1989) 
Uyar, Mesut-Edward J Erickson, A Military History of the Ottomans, (Santa Barbara: ABC Clio, 2009)

Yapıc1, Hakk1, Takvim-i Vekayi'de Kırım Harbi (1853-1856), (Erzurum: Atatürk Üniversitesi, 1999)

Yergök, Ziya, Sarıkamış’tan Esarete, Haz. Sami Önal, (İstanbul: Remzi Kitabevi, 2005), s. 124 